\title{
Small river plumes off the northeastern coast of the Black Sea under average climatic and flooding discharge conditions
}

\author{
Alexander Osadchiev ${ }^{1}$ and Evgeniya Korshenko ${ }^{2}$ \\ ${ }^{1}$ Shirshov Institute of Oceanology, Russian Academy of Sciences, Moscow, Russia \\ ${ }^{2}$ Zubov State Oceanographic Institute, Moscow, Russia \\ Correspondence to: Alexander Osadchiev (osadchiev@ ocean.ru)
}

Received: 2 January 2017 - Discussion started: 6 February 2017

Revised: 17 May 2017 - Accepted: 18 May 2017 - Published: 15 June 2017

\begin{abstract}
This study focuses on the impact of discharges of small rivers on the delivery and fate of fluvial water and suspended matter at the northeastern part of the Black Sea under different local precipitation conditions. Several dozens of mountainous rivers flow into the sea at the study region, and most of them, except for several of the largest, have little annual runoff and affect adjacent coastal waters to a limited extent under average climatic conditions. However, the discharges of these small rivers are characterized by a quick response to precipitation events and can significantly increase during and shortly after heavy rains, which are frequent in the considered area. The delivery and fate of fluvial water and terrigenous sediments at the study region, under average climatic and rain-induced flooding conditions, were explored and compared using in situ data, satellite imagery, and numerical modeling. It was shown that the point-source spread of continental discharge dominated by several large rivers under average climatic conditions can change to the linesource discharge from numerous small rivers situated along the coast in response to heavy rains. The intense line-source runoff of water and suspended sediments forms a geostrophic alongshore current of turbid and freshened water, which induces the intense transport of suspended and dissolved constituents discharged with river waters in a northwestern direction. This process significantly influences water quality and causes active sediment load at large segments of the narrow shelf at the northeastern part of the Black Sea compared to average climatic discharge conditions.
\end{abstract}

\section{Introduction}

Continental discharge is one of the main sources of terrigenous sediments, nutrients, and anthropogenic pollution in the sea and can significantly affect seabed morphology, water quality, primary productivity, and fishery in coastal areas (e.g., Emmet, 2006; Milliman et al., 2007; Zhou et al., 2008; Rabalais, 2010). Generally, the majority of fluvial runoff and the related discharge of its suspended and dissolved constituents on a regional scale are provided by the largest local rivers, and small rivers (i.e., rivers with small drainage basins and small annual discharges) usually play an insignificant role. Moreover, most of the world's small rivers are not covered by regular hydrological and discharge measurements, which results in a lack of information about their runoff volume and variability (Vorosmarty et al., 2001; Hrachowitz et al., 2013). Hence, studies that focus on the delivery and fate of river-borne dissolved and suspended matter in coastal zones generally consider only one or several of the largest rivers of a study area, and the influence of small local rivers is neglected.

However, under certain terrain and climatic conditions, the cumulative discharge from small rivers can greatly increase in response to heavy rains and become comparable to or even exceed the runoff of large rivers (Mertes and Warrick, 2001; Wheatcroft et al., 2010; Kniskern et al., 2011; Saldias et al., 2016). This rain-induced flooding discharge of small rivers can significantly influence the land-ocean fluxes of fluvial water, sediments, nutrients, and pollutants as well as modify the structure and intensity of coastal transport pathways for certain world regions, at least on a short-term scale, as addressed in a number of relevant studies (e.g., Milliman and 
Syvitski, 1992; Meybeck et al., 2003; Brodie et al., 2010; Hilton et al., 2011; Bao et al., 2015; Warrick and Farnsworth, 2017).

This article focuses on the impact of discharges of small rivers on the delivery and fate of fluvial water and suspended sediments on the northeastern coast of the Black Sea under different discharge conditions. We considered two trial periods in summer and autumn (25 May to 4 July 2011 and 619 September 2011), characterized by seasonal freshet and drought discharge conditions. Several flash-flooding events were registered during both periods, which influenced large segments (50-200 km long) of the coast.

Based on in situ data, satellite imagery, and numerical modeling, we reconstructed the daily volumes of fluvial water and terrigenous sediments discharged during the trial periods from the 20 largest rivers of the study region. To do this we used a recently developed method described in Osadchiev (2015). Then, using a nested combination of the Eulerian model INMOM (Institute of Numerical Mathematics Ocean Model) and the Lagrangian model STRiPE (SurfaceTrapped River Plume Evolution), we simulated the spread of buoyant plumes generated by these rivers during the trial periods in two modes characterized by different river discharge conditions. The first mode was run using reconstructed discharge data ("real" mode), whereas the second mode was run using smoothed discharge data; therefore, flash floods were substituted by periods of average seasonal discharge ("averaged" mode). Also, we simulated the transport and settling of river-borne terrigenous sediments discharged during the first trial periods for both discharge modes. Based on the obtained results of numerical modeling, we reconstructed the transport patterns of river-borne suspended sediments for normal and flash-flooding discharge conditions and showed the significant difference between them.

This article is organized as follows. Section 2 provides detailed information about the study region. Satellite and in situ data collected in the study region and used for model application and validation are described in Sect. 3. Description of the buoyant river plumes formed at the study area and reconstruction of the daily hydrographs of the 20 largest rivers of the study area are given in Sect. 4. Section 5 focuses on the general description of the numerical model used to reproduce the delivery and fate of fluvial water and river-borne terrigenous sediments. The results of numerical simulations of river discharge spread and transport of suspended sediments under average seasonal and flooding discharge conditions, as well as the related discussion, are given in Sect. 6. A brief summary and the conclusions are presented in Sect. 7.

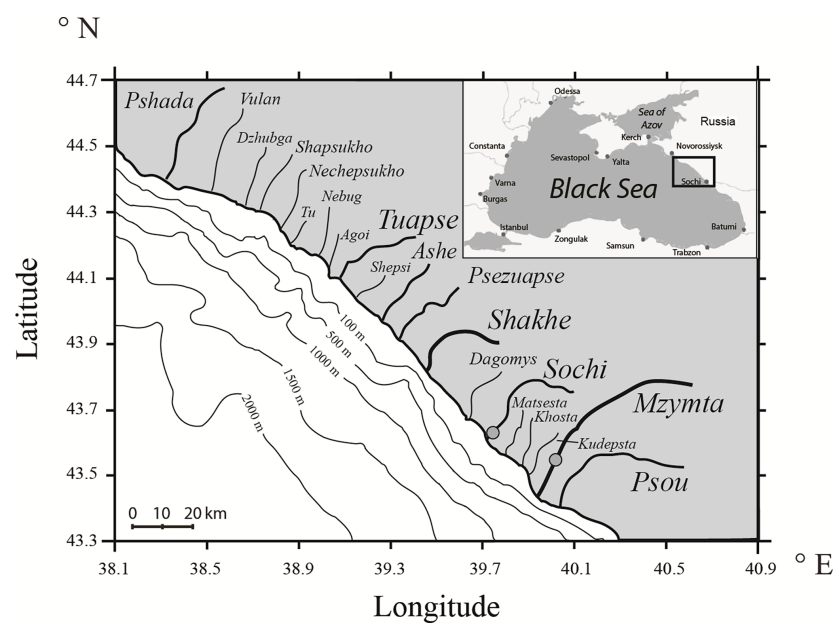

Figure 1. Location of the study region, disposition of the 20 largest rivers (thick black lines), gauge stations (gray circles at the Mzymta and Sochi rivers), and bathymetry of the coastal area.

\section{Study area}

\subsection{Topography and precipitation conditions}

The study region includes a $300 \mathrm{~km}$ section of the Russian coast of the Black Sea (RCBS) between the city of Novorossiysk and the city of Sochi (Fig. 1). The drainage basin of RCBS is a narrow area limited by the Greater Caucasus Range at the east and the sea coast at the west. The height of the Greater Caucasus Range increases from $400 \mathrm{~m}$ in the north to $3200 \mathrm{~m}$ in the south, whereas the distance between the range and the sea coast increases from 10 to $40 \mathrm{~km}$.

According to the Koppen climate classification, the study area lies in a humid subtropical zone (Cfa) with hot and humid summers and cold winters. The complex topography of RCBS greatly influences the local atmospheric circulation and the local precipitation regime. In particular, orographic lift induces frequent and intense rains at the southern side of the Greater Caucasus Range. The mean annual precipitation volume steadily increases (following the increase in height of the range) from $700 \mathrm{~mm}$ at the northern part of RCBS to $1700 \mathrm{~mm}$ at the southern part. The local precipitation is characterized by significant seasonal variability with a maximum in winter and a minimum in summer. However, intense precipitation events can occur in all months of the year; in particular, the maximal amount of daily rainfall at the study region $(298 \mathrm{~mm}$ ) was registered in June.

\subsection{River discharge}

The steep gorges located between the numerous spurs of the Greater Caucasus Range form the drainage basins of more than 50 rivers and watercourses, which flow into the sea at the study region. The areas of these basins are relatively small, and only eight of the considered rivers have annual dis- 
charges greater than $10 \mathrm{~m}^{3} \mathrm{~s}^{-1}$. The total annual continental runoff from RCBS to the sea is estimated as $7 \mathrm{~km}^{3}$ (Jaoshvili, 2002).

Discharge of the Mzymta River, which is the largest river of the study area, is characterized by a drought period in autumn and winter and a freshet in spring and early summer, associated with snow melting. The other rivers of RCBS are mainly rain-fed, and their annual runoff volume is formed mainly during short-term floods (15-25 annually) with sharp rises and falls of discharge caused by the following conditions. The steep slopes of the drainage basins (up to $40-60^{\circ}$ ) of these rivers and their small sizes (below $900 \mathrm{~km}^{2}$ ) and high drainage densities (0.85-1.05) cause the quick delivery of rain water into the river channels. As a result, discharge of these rivers to the sea can significantly increase over several hours in response to an active precipitation event (Balabanov et al., 2011; Alexeevsky et al., 2016). For example, the heavy rain on 31 July to 1 August 1991 caused an increase in discharge of the Tuapse River from 0.8 to $2300 \mathrm{~m}^{3} \mathrm{~s}^{-1}$ in less than $5 \mathrm{~h}$, whereas subsequent recession of its runoff lasted 3 days. Flooding periods are mainly registered during winter (November-March), which provides $65-80 \%$ of total annual discharge of the small rivers of RCBS.

According to Jaoshvili (2002), approximately $106 \mathrm{~m}^{3}$ of sediments are discharged from the RCBS rivers to the northeastern part of the Black Sea. Coarse sediments, which constitute approximately one-third of the total sediment volume, are deposited at shallow areas near the shore, whereas fine sediments are mainly transported offshore and settle on the deep ocean floor. The annual average suspended sediment concentrations in the rivers of the study area are 50$150 \mathrm{~g} \mathrm{~m}^{-3}$; however, the daily and seasonal values are characterized by significant variability. In particular, the average seasonal suspended sediment concentration in the Mzymta River varies between $48 \mathrm{~g} \mathrm{~m}^{-3}$ in February and $226 \mathrm{~g} \mathrm{~m}^{-3}$ in May, whereas the daily sediment concentrations vary between 0 and $11000 \mathrm{~g} \mathrm{~m}^{-3}$. On average, the concentration of suspended sediments in the Mzymta River exceeds $1000 \mathrm{~g} \mathrm{~m}^{-3}$ during 6 days in a year (Balabanov et al., 2011).

\subsection{Coastal circulation and bathymetry}

The bathymetry of the study region is characterized by the narrow shelf, and the distance from the shore to the $100 \mathrm{~m}$ isobath varies between 2 and $15 \mathrm{~km}$. Further offshore, the steep continental slope descends to a depth of $1000 \mathrm{~m}$ at a distance of $20-30 \mathrm{~km}$ from the shore (Fig. 1). Multiple underwater canyons are located at the continental shelf and continental slope of the study region. The narrowest shelf is located near the Pshada, Shakhe, Mzymta, and Psou river estuaries, and these areas are characterized by intense shelf erosion.

General water transport of the Black Sea is governed by a current system cyclonically circulating along the continental slope, which is generally referred to as the Black Sea
Rim Current (e.g., Oguz et al., 1992, 1993; Kortotaev et al., 2003). The velocity of the Rim Current at the northeastern part of the Black Sea is $0.2-0.5 \mathrm{~m} \mathrm{~s}^{-1}$. Coastal circulation in the study region is also influenced by nearshore anticyclonic eddies, which are regularly formed between the main flow of the Rim Current and the coast owing to baroclinic instability caused by wind forcing and coastal topography. The diameters of most of these eddies do not exceed $60 \mathrm{~km}$; however, the spatial scales of the largest eddies can be up to $160 \mathrm{~km}$. Nearshore anticyclonic eddies formed in the study region move in a northwestern direction along the continental slope with an average velocity of $0.02-0.04 \mathrm{~m} \mathrm{~s}^{-1}$, whereas their average rotating velocity is $0.05-0.4 \mathrm{~m} \mathrm{~s}^{-1}$ (Ginzburg et al., 2002; Zatsepin et al., 2003; Kubryakov and Stanichny, 2015a, b).

\section{Data}

The in situ measurements used in this study were performed during two field surveys organized by Shirshov Oceanology Institute on 28-30 May 2011 and 15-19 May 2012 at the southern part of RCBS (Fig. 1). Fieldwork took place in the coastal areas influenced by the Dagomys, Sochi, Matsesta, Khosta, Kudepsta, Mzymta, and Psou rivers. Field surveys included continuous measurements of salinity and concentrations of total suspended matter (TSM), colored dissolved organic matter (CDOM), and chlorophyll $a$ (Chla) at the surface layer at areas adjacent to the river estuaries. The measurements were performed along the ship track using a ship-mounted pump-through system equipped with a CTD (conductivity, temperature, and depth) instrument (SeaBird SBE911) and the ultraviolet fluorescent lidar (UFL-9) and were organized as cross-shore transects; the distances between neighboring transects near the river estuaries were $100-150 \mathrm{~m}$. Additionally, vertical profiles of salinity were measured within the river plumes using a CTD instrument (SeaBird SBE19plus). The explicit description of the lidar instrument and the algorithms used for retrieving TSM, CDOM, and Chl- $a$ are given in Palmer et al. (2013). Detailed information about the field surveys and the measurements described above can be found in Zavialov et al. (2014).

Satellite data used in this study included EnviSat MERIS L1 satellite imagery provided by the European Space Agency and L4 sea surface temperature (SST) products derived and distributed in the framework of the Copernicus Marine Environment Monitoring Service (CMEMS) project. EnviSat MERIS L1 satellite products with $300 \mathrm{~m}$ spatial resolution were used for retrieving maps of sea surface distributions of TSM, CDOM, and Chl- $a$ using the MERIS Case-2 Regional water processing module (Doerffer and Schiller, 2008). The resulting TSM and Chl- $a$ distributions were validated against the results of analysis of the water samples collected at the surface layer and optical remote sensing performed by lidar at the southern part of the study region. Daily gap-free SST 
maps of the Black Sea with $0.0625^{\circ}$ spatial resolution were obtained from the processing and statistical interpolation of nighttime measurements collected by infrared satellite sensors mounted on different satellite platforms. Details of SST data processing are described in Nardelli et al. $(2009,2013)$.

Meteorological data for the Black Sea area were calculated by the Weather Research and Forecasting (WRF) model (version 3.6) using the Lambert conformal conic projection with a horizontal spatial resolution of $10 \mathrm{~km}$. The vertical coordinate was represented by 35 levels, and the time step was set equal to $90 \mathrm{~s}$. Initial and boundary conditions for WRF were obtained from the National Centers for Environmental Prediction Final Analysis product. Finally, in this work we used daily gauge data of river discharge measured at the Sochi and Mzymta rivers (Fig. 1) and provided by the Federal Service for Hydrometeorology and Environmental Monitoring of Russia.

The in situ, satellite, and WRF model data described above were used for, first, evaluation of the river discharge for ungauged rivers of the study region (Sect. 4.2), and, second, application and validation of the numerical model, which reproduced the delivery and fate of fluvial water and river-borne terrigenous sediments at the northwestern part of the Black Sea during the simulation periods (Sect. 6). In particular, the ability of the numerical model to reproduce sub-mesoscale variability of the river plumes of RCBS, which is crucial for this study, was proved based on the salinity and TSM in situ data collected during 28-30 May 2011 on the field cruise (Sect. 6.1).

\section{River plumes at RCBS}

\subsection{Structure and variability of river plumes}

Multiple rivers of RCBS form buoyant plumes adjacent to the river estuaries. Under average climatic discharge conditions, the most extensive river plume is generated by the Mzymta River, the largest river of the study area, whose mean monthly discharge varies between 20 and $120 \mathrm{~m}^{3} \mathrm{~s}^{-1}$.

Generally, the Mzymta plume occupies less than $10 \mathrm{~km}^{2}$ of the coastal zone and its depth does not exceed $5 \mathrm{~m}$; however, during spring and summer freshet periods, it can increase up to $50 \mathrm{~km}^{2}$. The horizontal and vertical spatial scales of the other river plumes of RCBS are even smaller except for short-term periods of flooding discharge induced by heavy rains. An example of surface salinity distributions and vertical salinity profiles near a river estuary for small (Sochi, $16 \mathrm{~m}^{3} \mathrm{~s}^{-1}, 17$ May 2012) and large (Mzymta, $81 \mathrm{~m}^{3} \mathrm{~s}^{-1}, 18$ May 2012) river plumes is shown in Fig. 2.

The rivers of the study region are characterized by elevated concentrations of suspended sediments compared to sea water. As a result, salinity correlates well with turbidity at the surface layer and the river plumes can be effectively detected by optical satellite imagery, as addressed in
Zavialov et al. (2014) and Osadchiev (2015) (Fig. 3). Thus, ocean color remote sensing is an efficient tool for monitoring river plumes at the study region.

Both in situ and satellite measurements revealed high spatial and temporal variability of the river plumes of RCBS. Their area, form, and shape can significantly change in less than 1 day in response to variations of river discharge and local wind forcing (Korotkina et al., 2011, 2014; Zavailov et al., 2014). Under average discharge conditions, the river plumes are distinctly separated because their spatial scales do not exceed the distances between the river estuaries. However, during rain-induced floods, the areas of the river plumes significantly increase, and the plumes can collide and coalesce with neighboring plumes. The most intense precipitation events cause the formation of a continuous coastal strip of turbid water, which can be observed by satellite imagery (Fig. 3b). After the end of a flooding period, this strip dissipates and river plume areas decrease to their average seasonal sizes (Fig. 3c).

\subsection{Reconstruction of river discharge}

In this work, we explored discharges of the 20 largest rivers of the study region. The list of them, sorted from north to south, is as follows: Pshada, Vulan, Dzhubga, Shapsukho, Nechepsukho, Tu, Nebug, Agoi, Tuapse, Shepsi, Ashe, Psezuapse, Shakhe, Dagomys, Sochi, Matsesta, Khosta, Kudepsta, Mzymta, and Psou. These rivers are estimated to provide approximately $95 \%$ of the annual runoff of fluvial water and sediments from RCBS (Jaoshvili, 2002).

The Mzymta and Sochi rivers are the only rivers of the study region with available daily gauge measurements during the trial periods (25 May to 4 July 2011 and 6-19 September 2011). Discharge volumes of the other 18 rivers were evaluated using the method described in Osadchiev (2015). The general idea of this method is to use satellite-derived properties of a river plume for reconstruction of the conditions of its formation, in particular river discharge volume. First, the spatial extent and the shape of the river plume are identified by satellite imagery. Second, a hydrodynamic model, which simulates the formation of river plumes, is run with a variety of forcing conditions to identify the discharge rate that provides the best match between modeled and observed plumes.

The numerical model, based on the method described above, was tuned for the Mzymta and Sochi rivers and validated against gauge data. This model analyzed TSM, CDOM, and Chl- $a$ distribution maps derived from EnviSat MERIS satellite imagery to identify river plumes at the study area. Then, it applied the STRiPE model for simulating the formation of river plumes. Details of the method, the numerical model, and its validation are given in Osadchiev (2015). After passing the validation procedure, the model was applied to quantify the discharge of ungauged rivers of RCBS during the trial periods. The discharge values for the considered rivers were obtained for 11-13 out of 41 days of the first 

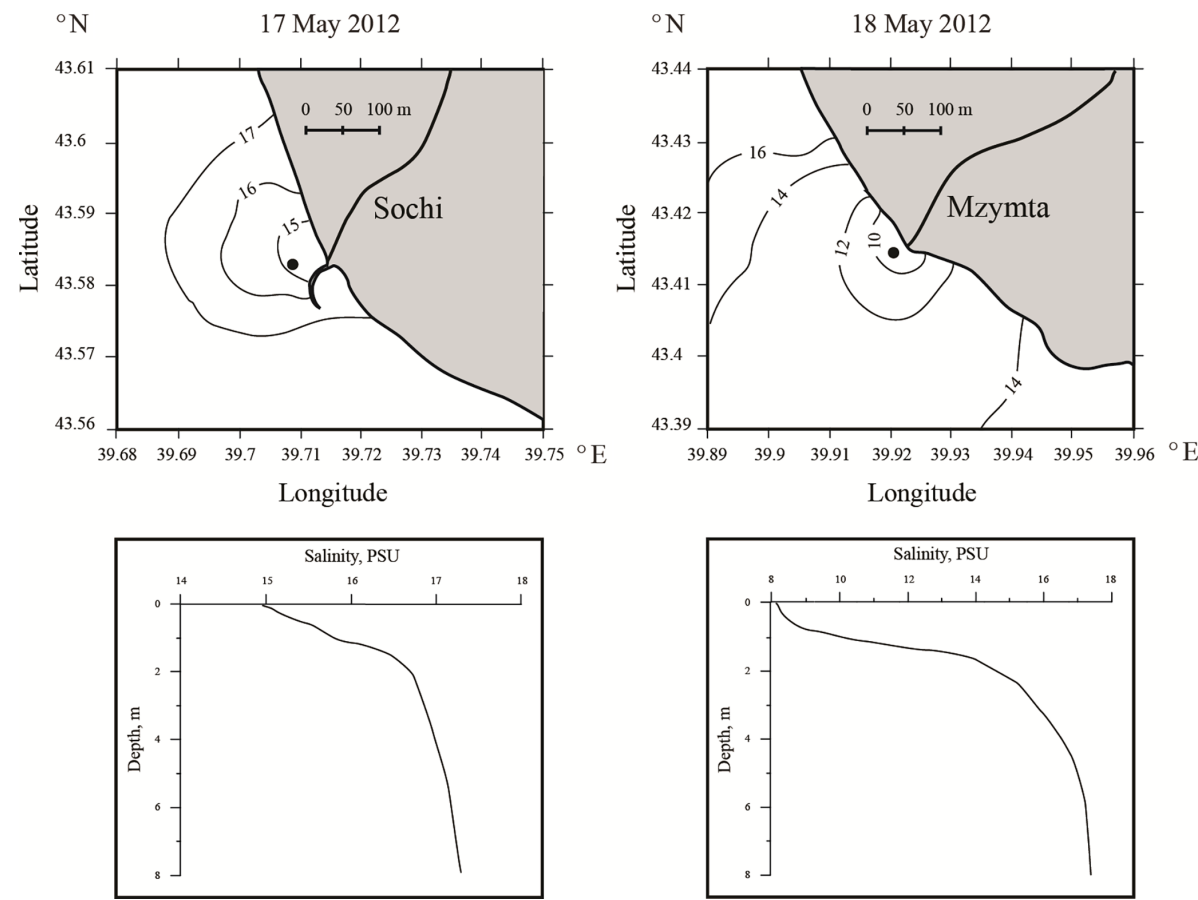

Figure 2. Surface salinity distributions (top panel) and vertical salinity profiles (bottom panel) at the Sochi plume on 17 May 2012 (left) and at the Mzymta plume on 18 May 2012 (right).
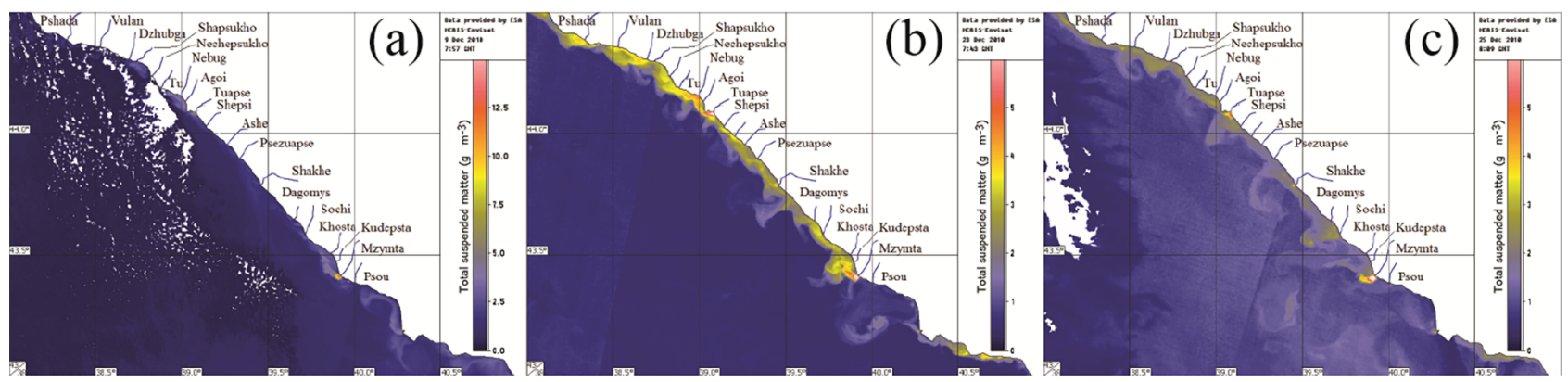

Figure 3. Satellite-derived surface TSM distribution at RCBS (a) before, (b) during, and (c) after a flash-flooding event.

trial period and for $6-8$ out of 14 days of the second trial period. The number of days with reconstructed discharge is not the same for the considered rivers, because it depends on the feasibility of identification of river plumes, i.e., availability of cloud-free satellite imagery at the respective coastal areas.

However, discharge values during the days of the trial periods, which were not covered by appropriate satellite images, remained unknown. They were prescribed based on reconstructed discharge data and WRF precipitation data in the following manner. The satellite-derived discharge values revealed relatively uniform river runoff during the trial periods, except for several short-term flooding events with significantly elevated discharge. The flash floods at the rivers showed good correlation with the rain events at the respective river basins reconstructed by the WRF model. These rain events were observed during 25-27 May, 30 May, 21-
23 June, and 27-30 June in the first trial period and during 9-12 September in the second trial period. Based on this, we presumed that periods of peak discharge during the flooding events correspond to periods of active precipitation registered at the respective river basin. Thus, the satellite-derived discharge values were linearly extrapolated until the day of the formation of a flooding event, followed by a sharp increase in discharge to the peak value and a linear decrease to the average discharge conditions after the end of a flooding event.

The resulting hydrographs of the Shakhe, Sochi, Mzymta, and Psou rivers (whose annual runoff is greater than $15 \mathrm{~m}^{3} \mathrm{~s}^{-1}$ ), hereinafter referred to as the large rivers of RCBS, are presented in Fig. 4 together with the variation of the total discharge of the other 16 rivers, hereinafter referred to as the small rivers of RCBS. The measured and reconstructed discharges of fluvial water from the 20 largest rivers 


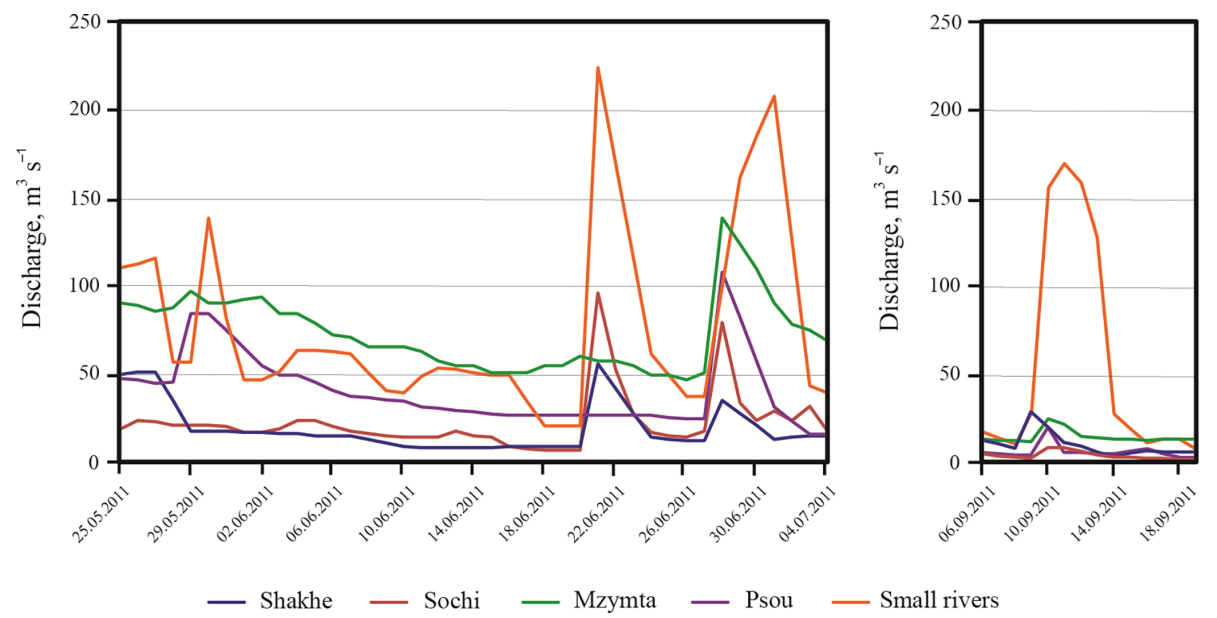

Figure 4. Daily discharge rates of the rivers of RCBS during 25 May to 4 July 2011 (left) and 6-19 September 2011 (right), measured at the gauge stations (for the Mzymta and Sochi rivers) and reconstructed using satellite imagery and numerical modeling (for the Shakhe, Psou, and small rivers).
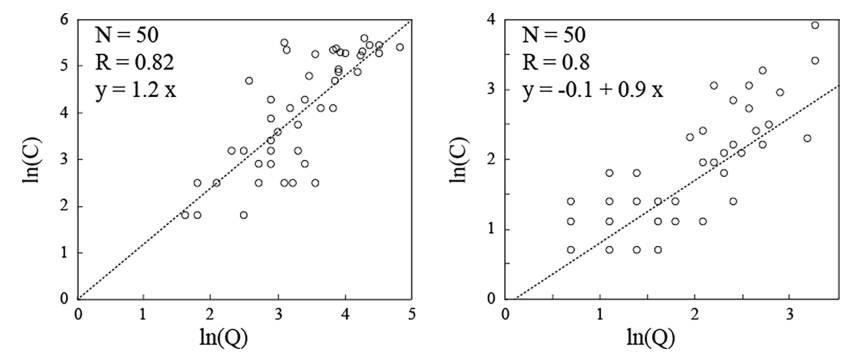

Figure 5. Logarithmic dependences of TSM concentrations $(C$, $\left.\mathrm{g} \mathrm{m}^{-3}\right)$ on river discharge rates $\left(Q, \mathrm{~m}^{3} \mathrm{~s}^{-1}\right)$ for the large (left) and small (right) rivers of RCBS.

of RCBS show that continental runoff is dominated by several of the largest rivers of the study region during periods of average seasonal discharge. The Shakhe, Sochi, Mzymta, and Psou rivers provided $65-85 \%$ of daily continental runoff during the trial periods. Flooding events significantly change this proportion, especially during autumn drought, when the average seasonal discharge rates of all the rivers of the study area are relatively low. In particular, the share of the large rivers of RCBS in total runoff during the flash floods decreased to $45 \%$ during the first trial period and to $20 \%$ during the second trial period.

After evaluation of the daily river discharge values, we reconstructed the daily concentrations of suspended sediments at the near-field parts of the considered river plumes, which were used as input data for the numerical modeling addressed in Sect. 6. First, the TSM concentrations were retrieved from the satellite and in situ data for the respective days of the trial periods. They showed strong logarithmic dependence on the reconstructed river discharge values separately within the large rivers and the small rivers of RCBS (Fig. 5). The Pearson correlation coefficient between $\ln (C)$ and $\ln (Q)$ was equal to 0.82 for the large rivers and 0.8 for the small rivers, where $C$ is the TSM concentration $\left(\mathrm{g} \mathrm{m}^{-3}\right)$ and $Q$ is the river discharge $\left(\mathrm{m}^{3} \mathrm{~s}^{-1}\right)$. A t-test showed that both correlations were significant at the 0.01 level. Based on this, we used the obtained equations $C=Q^{1.2}$ for large rivers and $C=9 Q^{0.9}$ for small rivers, which are consistent with previous studies (Jaoshvili, 1986; Balabanov et al., 2011), for reconstructing the daily variability of TSM concentrations of the rivers of RCBS during the trial periods.

\section{Model}

In this work, we applied numerical modeling to study the delivery and fate of fluvial water and terrigenous sediments at RCBS under average seasonal and flooding river discharge conditions. Accurate simulation of the sub-mesoscale river plume dynamics are essential for the correct reconstruction of the transport, mixing, and settling of fluvial water and suspended sediments in the coastal area. On the other hand, correct simulation of the mesoscale coastal circulation is also important, because it, first, influences river plume dynamics and, second, governs the transport and settling of river-borne suspended sediments after they sink beneath the plumes into the ambient ocean. For this reason, we used a nested combination of Eulerian and Lagrangian numerical models, which accurately reproduce both the mesoscale sea circulation and the sub-mesoscale dynamics of multiple river plumes of the study area.

River-borne terrigenous sediments are tracked as passive tracers of river outflow. Initially, tracers are transported by buoyant plume waters whose dynamics are simulated by the STRiPE model. After the sediment particle settles beneath the plume, its movement is governed by ambient coastal circulation, reproduced by the INMOM model. The similar con- 
figuration of coupled Eulerian (Princeton Ocean Model) and Lagrangian (STRiPE) models was recently used for simulation of the delivery and fate of fluvial water and terrigenous sediments discharged by the Peinan River at the southeastern coast of the island of Taiwan under freshet and typhoon discharge conditions (Osadchiev et al., 2016) and for studying the dynamical features of the Zhuoshui and Wu river plumes located on the western coast of Taiwan (Korotenko et al., 2014).

\section{$5.1 \quad$ INMOM model}

An outer Eulerian model is INMOM, a $\sigma$-coordinate ocean circulation model based on the primitive equations of ocean hydrothermodynamics with the Boussinesq and hydrostatic approximations. The global version of INMOM was used as the oceanic component of the IPCC climate model INMCM in the framework of the Coupled Model Intercomparison Project Phase 5 (Volodin et al., 2010) as well as for modeling the Arctic Ocean (Johnson et al., 2012) in the framework of the Arctic Ocean Model Intercomparison Project, and the South Ocean (Downes et al., 2015; Farneti et al., 2015) and North Atlantic Ocean (Danabasoglu et al., 2016) in the framework of the Coordinated Ocean-ice Reference Experiments.

In this study, we used a regional version of INMOM developed for the Black Sea. It uses polar coordinates for the horizontal dimensions and $\sigma$-coordinates for the vertical dimension. The INMOM model domain covers the whole Black Sea basin to avoid open boundaries (Fig. 6). It is divided into $642 \times 715$ horizontal grid points (radius and azimuth), and the pole is located at $\operatorname{RCBS}\left(40.205^{\circ} \mathrm{E}, 43.84^{\circ} \mathrm{N}\right)$. The INMOM horizontal spatial resolution increases from $200 \mathrm{~m}$ at the northeastern part of the Black Sea to $4.5 \mathrm{~km}$ at its southwestern part. Thus, INMOM, on the one hand, reproduces mesoscale circulation of the whole Black Sea with moderate spatial resolution and, on the other hand, provides high spatial resolution at the study region, which is an important advantage of INMOM compared to other Eulerian ocean models in the context of this work. Several studies used this regional version of INMOM for studying aspects of the general circulation of the Black Sea (Zalesny et al., 2012, 2013) and the coastal circulation at RCBS (Diansky et al., 2013; Zalesny et al., 2016a, b).

A Laplacian operator along isopycnic surfaces is used for parameterization of the lateral diffusion of salinity and temperature, whereas a bi-Laplacian operator along the $\sigma$ surface is used for the lateral viscosity on momentum (Volodin et al., 2010). The vertical coordinate is represented by $20 \sigma$-levels with irregular vertical spacing to provide higher resolution near the surface. The vertical viscosity and diffusion coefficients were parameterized as a function of the Richardson number according to the Pacanowsky and Philander scheme (Pacanowsky and Philander, 1981). The minimum water depth in the model domain was set equal to $3.5 \mathrm{~m}$.

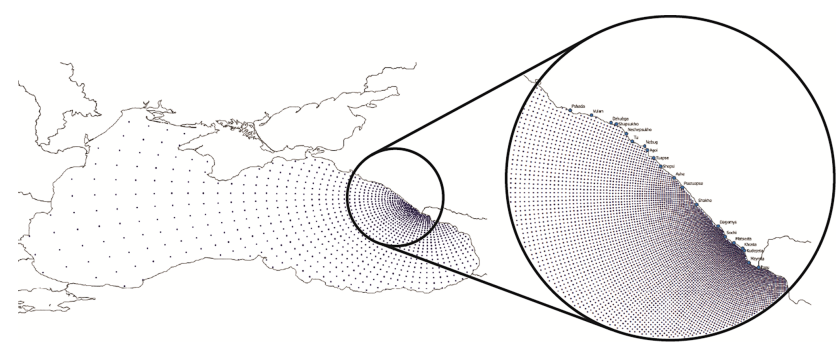

Figure 6. INMOM model domain at the Black Sea (every 15th grid point is shown) (left) and at RCBS (every 4th grid point is shown) with indication of the location of the considered river estuaries (right).

Surface and lateral boundary conditions for the INMOM model runs were set in the following manner. No heat and salt flux as well as no flow across the bottom and lateral solid boundaries were prescribed. No-slip and quadratic bottom friction conditions with drag coefficient $C_{\mathrm{d}}$ equal to $2.5 \times 10^{-3}$ were applied to the lateral and bottom boundaries, respectively. The surface turbulent fluxes are calculated using bulk formulas. The INMOM model was forced with climatological runoff of the 14 largest rivers flowing into the Black Sea and water transport through the Kerch and Bosporus straits, which were set according to the data provided in Jaoshvili (2002). Atmospheric forcing was adopted from the WRF data set. Tidal currents at the Black Sea are low and do not significantly influence general sea circulation (Gregg and Ozsoy, 1999); therefore, tidal forcing was not considered in numerical modeling. The INMOM model was initialized using the monthly-averaged climatic temperature and salinity fields with $25-50 \mathrm{~km}$ spatial resolution (Ivanov and Belokopytov, 2013) as initial background conditions and provided ambient velocity fields for the STRiPE and sediment transport models. Owing to inaccuracy of available precipitation and river discharge, corrections of the simulated SST and sea surface salinity (SSS) fields were applied using daily satellite SST products provided in the framework of the CMEMS project (Nardelli et al., 2009, 2013) and monthlyaveraged climatic fields of the SSS of the Black Sea described above. The model time step was set equal to $90 \mathrm{~s}$.

\subsection{STRiPE model}

INMOM provides boundary conditions for the inner STRiPE model, which was developed for high-resolution simulation of the sub-mesoscale dynamics of buoyant river plumes. STRiPE is a Lagrangian model that reproduces a river plume as a set of imaginary "particles", i.e., homogeneous elementary water columns of reduced salinity extending from the surface down to the boundary between the plume and the underlying sea water. These particles are discharged into the sea from river estuaries, and their initial velocity and height are governed by the river discharge rate and river estuary depth, 
respectively. The subsequent motion of individual particles and their mixing with the underlying sea water are tracked by the model. The overall set of particles represents the river plume, and hence the temporal evolution of the plume structure is obtained. The main advantage of STRiPE lies in its ability to provide realistic results at relatively low computational cost compared to Eulerian models. STRiPE was applied for studying plumes formed by small- and medium-size rivers of RCBS by Osadchiev and Zavialov (2013) and Osadchiev (2015).

The STRiPE model domain covers the area from 38.0 to $40.2^{\circ} \mathrm{E}$ and from 43.1 to $44.6^{\circ} \mathrm{N}$. The STRiPE model was forced by WRF wind forcing, coastal circulation provided by the INMOM model, and river discharge prescribed according to the data described in Sect. 4.2. The initial inflow velocities of the rivers $w_{i}$ were calculated using the Manning formula $w_{i}=0.3\left(\frac{Q_{i}}{L_{i}}\right)^{0.4}$, where $Q_{i}$ is the river discharge and $L_{i}$ is the width of the river mouth. The river and ambient sea water densities were given as 1000 and $1017 \mathrm{~kg} \mathrm{~m}^{-3}$, respectively. The model time step was set equal to $90 \mathrm{~s}$.

\subsection{Sediment transport model}

The transport and settling of fine suspended sediments discharged from the river mouth was simulated using a Lagrangian particle-tracking model. Both the horizontal and vertical movements of a sediment particle were calculated using a combination of a deterministic component defined by motion of ambient water and sinking of a particle under gravity force and a stochastic random-walk scheme that reproduces the influence of small-scale turbulent mixing. Particles are initially released from the river mouth, and their horizontal transport is determined by the internal dynamics of a river plume simulated by the STRiPE model. After the sediment particle settles beneath the plume, its movement is governed by ambient coastal circulation, reproduced by the INMOM model. The detailed description of the sediment transport model is given in Osadchiev et al. (2016). TSM concentrations of river water were prescribed according to the data described in Sect. 4.2, whereas the sediment grain distribution was set based on the granulometric analysis of suspended sediments of water samples collected at the considered rivers during field surveys.

\subsection{Model validation}

The INMOM model simulated general circulation of the Black Sea during the period from January to September 2011. In this work, we considered the upper ocean dynamics for a regional model of the Black Sea with daily SST and monthly SSS data assimilation. As a result, the model reached a statistically steady state after a relatively short spin-up period of 5 months (January-May 2011). The main large-scale and mesoscale circulation features described in Sect. 2.3 were adequately reproduced by numerical model-
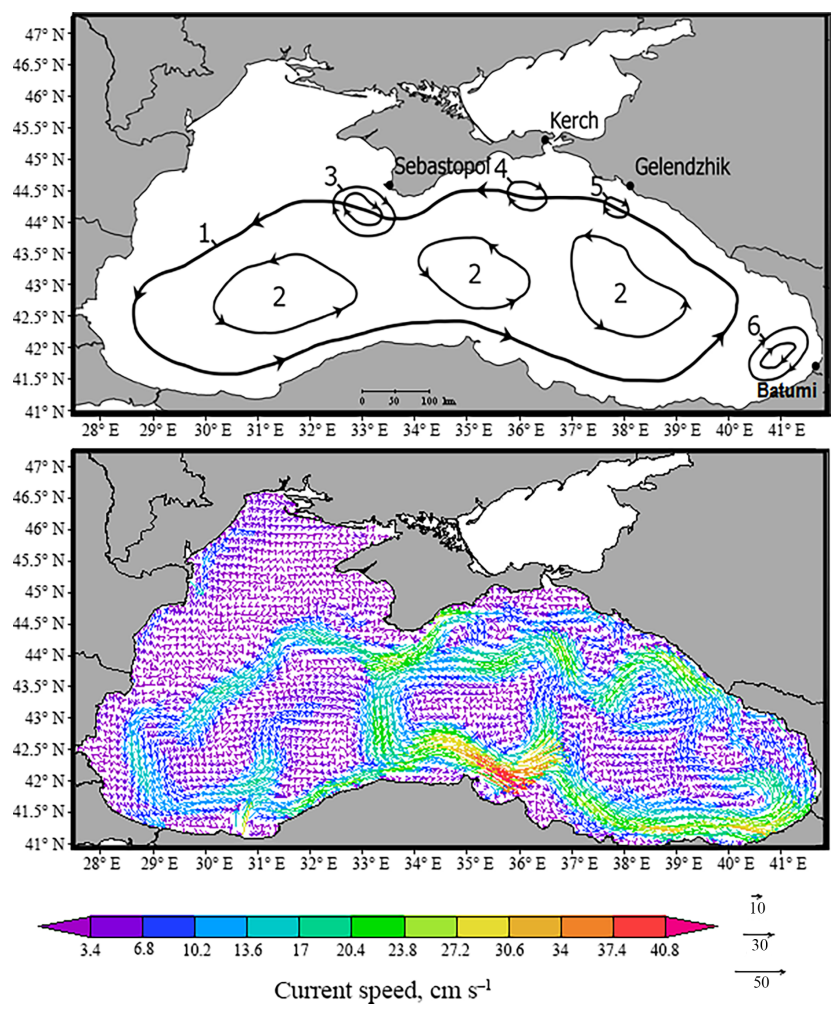

Figure 7. General surface circulation scheme of the Black Sea (top panel; 1 - mean position of the cyclonic Rim Current; 2 quasi-stationary cyclonic gyres; 3 - Sebastopol; 4 - Kerch; 5 - Gelendzhik; 6 - Batumi quasi-stationary anticyclonic gyres) and the INMOM modeled Black Sea circulation at a depth of $10 \mathrm{~m}$, averaged for June 2011 (bottom panel).

ing, including the Black Sea Rim Current, the three quasistationary cyclonic gyres at the central divergence zone, and the four quasi-stationary anticyclonic gyres at the eastern part of the Black Sea near Sebastopol, Kerch, Batumi, and Gelendzhik (Oguz et al., 1992, 1993, 1995; Stanev, 1995; Staneva et al., 2001). These features are visible in Fig. 7, which shows the modeled Black Sea current field at a depth of $10 \mathrm{~m}$ projected on a uniform grid with $10 \mathrm{~km}$ spatial resolution and averaged for June 2011. The model also reproduced seasonal variations of sea surface circulation, in particular winter-spring intensification of the Rim Current, meandering of the main flow of the Rim Current caused by baroclinic instability, and formation of multiple nearshore anticyclonic eddies during summer at the eastern part of the Black Sea (Oguz et al., 1992, 1993; Titov, 2002; Zatsepin et al., 2003; Enriquez et al., 2005). The simulated main flow of the Rim Current shifts offshore (approximately $45 \mathrm{~km}$ ) in June and its speed decreases to $20 \mathrm{~cm} \mathrm{~s}^{-1}$ (Fig. 7), which is in good agreement with the in situ measurements described by Titov (2002).

The nested model was applied to simulate the dynamics of the river plumes of RCBS during the trial periods, 25 May 

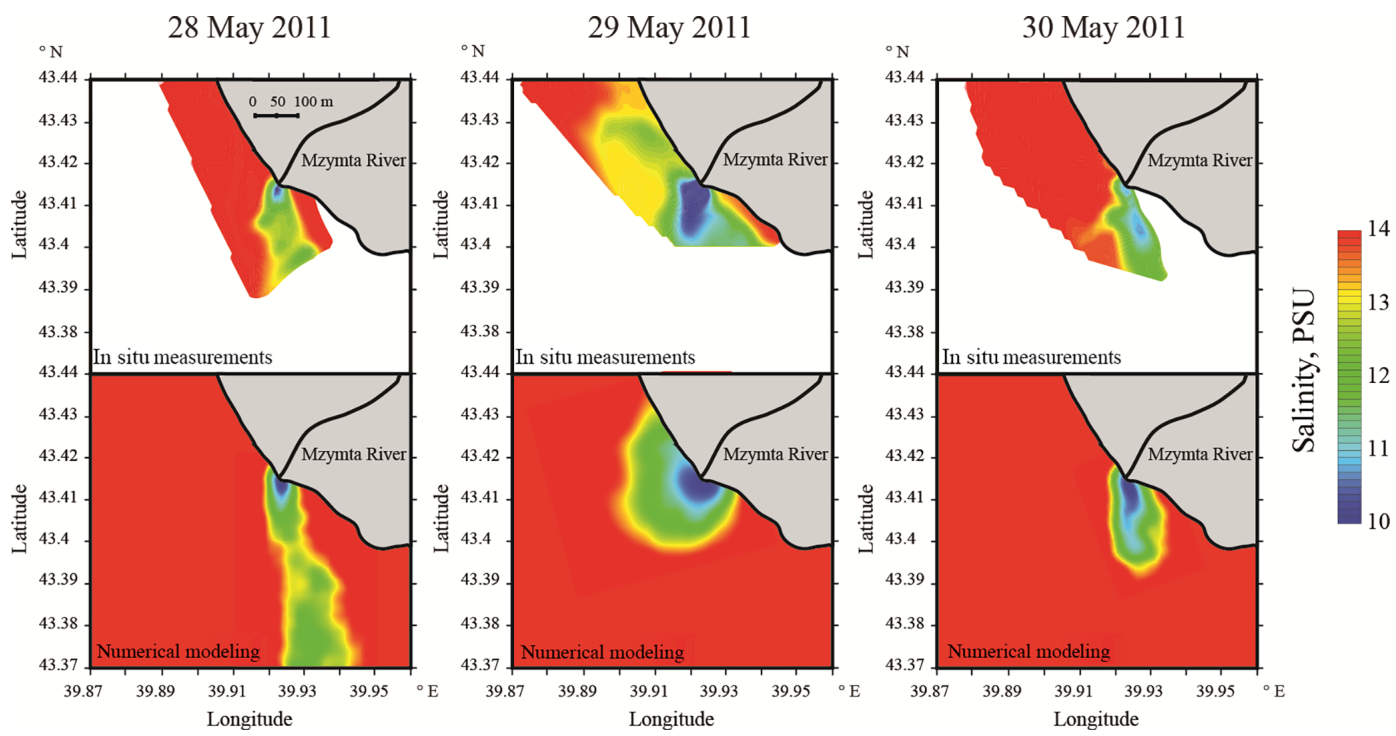

Figure 8. Measured (top panel) and modeled (bottom panel) surface salinity distributions near the Mzymta River estuary on 28-30 May 2011.

to 4 July 2011 and 6-19 September 2011. Most of the days within these periods were characterized by typical springsummer freshet and autumn drought conditions. The model at every time step outputs surface distributions of salinity and suspended sediments; thus, real mode simulations were validated against in situ salinity (Fig. 8) and TSM (Fig. 9) measurements as well as satellite-derived TSM distribution maps (Figs. 10 and 11).

The low computational cost of the Lagrangian model STRiPE enabled us to reproduce the dynamics of individual river plumes with high spatial resolution. In particular, the model adequately reproduced sub-mesoscale variability of the Mzymta plume observed during the field survey on 28-30 May 2011, which is illustrated by Figs. 8 and 9. The spring freshet discharge of the Mzymta River was equal to $90-100 \mathrm{~m}^{3} \mathrm{~s}^{-1}$ at the end of May 2011. On 28 and 30 May 2011, the Mzymta plume was stretched in a southern direction from the river mouth in response to moderate northerly and northwesterly wind. However, a significantly different wind forcing and, therefore, plume position and shape were observed on 29 May 2011. The Mzymta plume was arrested near the estuary by a slight onshore wind, which caused an increase in its area and a salinity anomaly near the estuary. The average positions of the simulated plume corresponding to 12:00-18:00 LT on 28-30 May 2011 illustrate this significant displacement and show good agreement with the salinity maps of the region obtained from the continuous CTD measurements in the surface layer (Fig. 8).

The simulated sediment distribution within the Mzymta plume was also validated against the in situ data. For this purpose, we used continuous measurements of TSM concentration in the surface layer carried out by the ultraviolet fluorescent lidar during the field survey and compared them with the simulated concentrations of suspended sediments. Both field data and numerical modeling showed that surface waters with elevated turbidity corresponded to the position of the plume during the whole simulation period (Fig. 9). Sediment concentration in the study region increased on 29 May in response to slight wind forcing, which was reproduced by numerical modeling.

\section{Results and discussion}

Numerical simulations were organized in the following manner. The validated model was applied to simulate the dynamics of the river plumes formed by the 20 largest rivers of RCBS and the related delivery and fate of fine terrigenous sediments during two trial periods, 25 May to 4 July 2011 and 6-19 September 2011. The main reason for selection of these trial periods was their good coverage by optical remote sensing. A cloudless coastal area of RCBS was visible by EnviSat MERIS satellite imagery for 17 out of 41 days of the first period and for 9 out of 14 days of the second period.

The first model run (25 May to 4 July 2011, real mode) represented typical spring-summer freshet discharges of the large rivers of RCBS and relatively low discharges of small rivers. The second model run (6-19 September 2011, real mode) simulated typical autumn drought discharge conditions for all rivers of the study region. Four intense rain events (25-27 May, 30 May, 21-23 June, and 27-30 June) during the first trial period and one (9-12 September) during the second trial period caused a considerable increase in discharge of small rivers and a subsequent decrease to average seasonal values, as discussed in Sect. 1. The third and fourth model runs (averaged modes) reconstructed the spread 

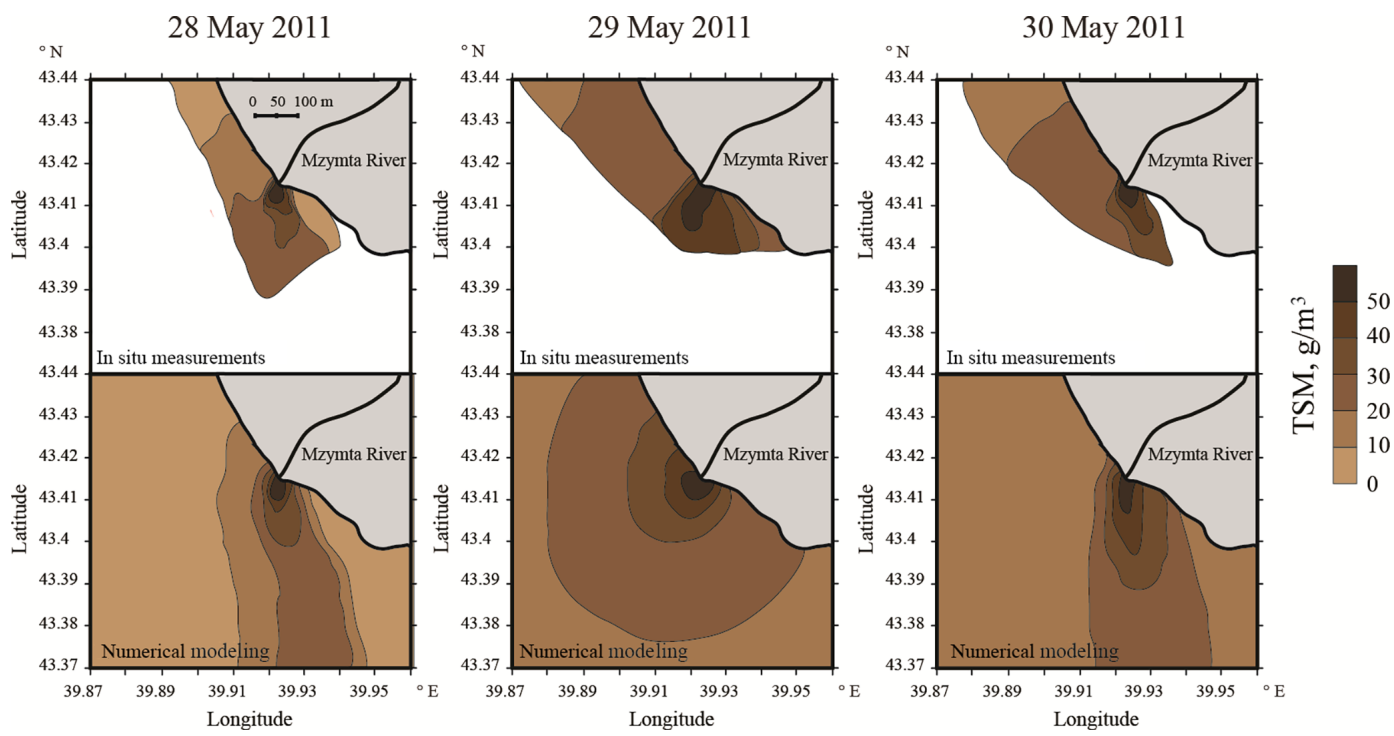

Figure 9. Measured (top panel) and modeled (bottom panel) surface TSM distributions near the Mzymta River estuary on 28-30 May 2011.

of river plumes during the trial periods under seasonal discharge conditions without flash floods. For this purpose, the real river discharge values were averaged over a period of 10 days. As a result, the total discharge volumes of fluvial water did not change, but their daily hydrographs were significantly modified during the flooding periods, i.e., the discharge peaks were significantly smoothed.

We also simulated the transport and settling of river-borne suspended sediments discharged during the first trial period under real and averaged conditions and reconstructed distributions of fine sediments deposited on the seabed in the study area. Thus, numerical simulations in the averaged mode reproduced the delivery and fate of fluvial water and suspended matter under average climatic discharge conditions, i.e., in the absence of flash floods, whereas real model runs combined both average climatic and flooding discharge conditions. Therefore, comparing the model outputs in real and "average" modes, we can distinguish the effect of short-term but intense flash-flooding events on the transport, mixing, and settling of fluvial water and terrigenous sediments at the study area. In particular, based on the analysis and comparison of the obtained results of the real and averaged model runs, we reconstructed the transport patterns of river-borne suspended sediments for normal and flash-flooding discharge conditions during freshet and drought seasons.

\subsection{Flash floods under real discharge conditions}

The typical example of a significant increase in the areas of buoyant plumes, formed by the rivers of RCBS along a large segment of the coast in response to an active precipitation event, and their subsequent decrease was observed on 26 June to 4 July 2011 (Figs. 10 and 11). On 26 June 2011, the Mzymta River was the only significant source of fluvial water and terrigenous sediments at the coastal area of RCBS, hereinafter referred to as the point-source discharge pattern. The Mzymta plume was stretched along the shore in a northern direction, and its area was approximately $30 \mathrm{~km}^{2}$. Plumes formed by the Psou, Sochi, and other smaller rivers of RCBS on 26 June 2011 were considerably smaller than the Mzymta plume. Their spatial scales did not exceed 1-2 km, and their impact on coastal water quality was negligible. The suspended sediment discharge rate from the Mzymta River was $4.8 \mathrm{~kg} \mathrm{~s}^{-1}$, whereas the total sediment discharge from the other modeled rivers of RCBS was slightly more than half $\left(2.5 \mathrm{~kg} \mathrm{~s}^{-1}\right)$. River-borne terrigenous sediments were transported northward by the Mzymta plume, the coarse fraction was deposited mainly along the shore near the Mzymta estuary, and the fine fraction was transported offshore by ambient coastal circulation.

Heavy rains, which lasted during 27-30 June 2011, affected most of the rivers of RCBS and caused a rapid and substantial rise of continental discharge of fluvial water and suspended sediments, especially from the small rivers of the study region (Fig. 4). On 29 June, individual river plumes coalesced into a continuous coastal strip of freshened (14-17 PSU) and turbid (2.5-7.5 $\left.\mathrm{g} \mathrm{m}^{-3}\right)$ water between the Dzhubga and Psou rivers (Fig. 10). This strip was formed by multiple sources located along the shore, hereinafter referred to as the line-source discharge pattern. Its alongshore length exceeded $150 \mathrm{~km}$, whereas its cross-shore width was approximately $5 \mathrm{~km}$, which is equal to the local internal Rossby radius. However, near the estuaries of the large rivers of RCBS, the width of the strip increased to $10-15 \mathrm{~km}$, and its depth was up to $5 \mathrm{~m}$. The discharge of suspended sediments increased by 1 order of magnitude and was equal to 25$50 \mathrm{~kg} \mathrm{~s}^{-1}$ for the Mzymta River; $10-25 \mathrm{~kg} \mathrm{~s}^{-1}$ for the Psou; Shakhe, and Sochi rivers; and $1-5 \mathrm{~kg} \mathrm{~s}^{-1}$ for the small rivers 


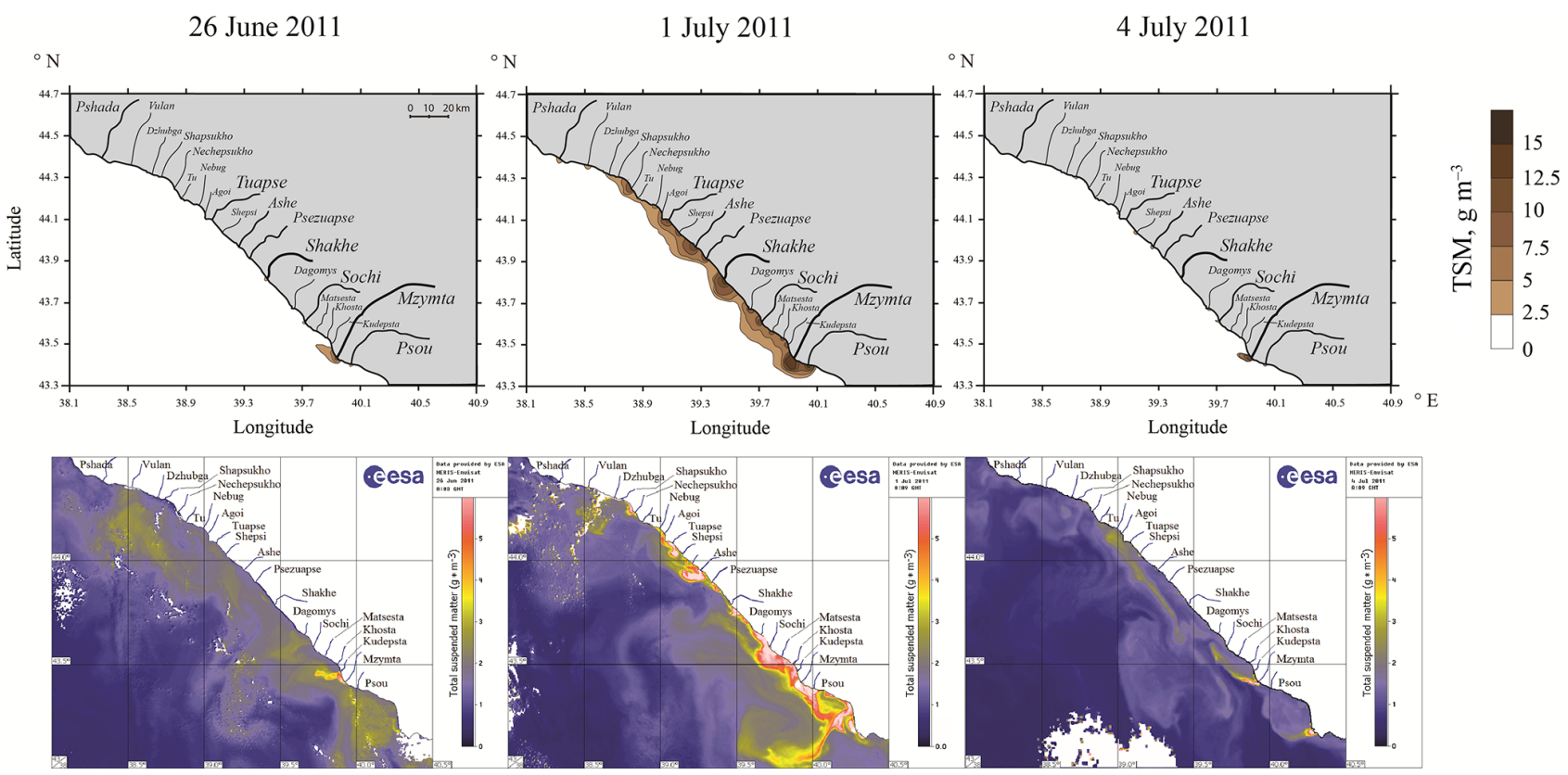

Figure 10. Modeled real mode (top panel) and satellite-derived (bottom panel) surface TSM distributions at RCBS on 26 June, 1 July, and 4 July 2011.

of RCBS. As a result, large volumes of coarse sediments were deposited near multiple river estuaries along the shore. The intense line-source discharge also caused the formation of a strong alongshore geostrophic current (up to $40 \mathrm{~cm} \mathrm{~s}^{-1}$ ) within the freshened strip, which is typical for far-field regions of river plumes (e.g., Garvine, 1987; O’Donnell, 1990; Fong and Geyer, 2002; Horner-Devine et al., 2006). This surface current caused intense transport of fine terrigenous sediments in the direction of Kelvin wave propagation, i.e., in a northwestern direction.

After the end of the peak discharge period, the line-source discharge pattern switched to the point-source pattern, and the freshened strip steadily diminished over several days and eventually dissipated on 3 July. Distributions of salinity and TSM at the study area on 4 July were similar to those observed before the flooding event (Fig. 10). The only large river plume (approximately $20 \mathrm{~km}^{2}$ ) was formed by the Mzymta River, and the areas of the other river plumes decreased to their average seasonal scales.

The influence of three other flash-flooding events (25-27 May, 30 May, and 21-23 June 2011) on coastal waters during the first trial period was also reconstructed by numerical modeling. The heavy rain event, which took place at the southern part of the study region during 21-23 June 2011, caused the formation of a line-source discharge pattern between the Shakhe and Mzymta rivers. Discharge of fluvial water and suspended sediments from the individual rivers increased by 1 (from $1-10$ to $20-100 \mathrm{~m}^{3} \mathrm{~s}^{-1}$ ) and 2 (from $0.01-0.1$ to $2.5-25 \mathrm{~kg} \mathrm{~s}^{-1}$ ) orders of magnitude, respectively. The freshened and turbid strip between the Shakhe and
Mzymta rivers (60 km long) was observed during 21-24 June and dissipated on 25 June. Alongshore geostrophic current was also wide (up to $15 \mathrm{~km}$ ), but less intense (up to $25 \mathrm{~cm} \mathrm{~s}^{-1}$ ), compared to that observed at the end of June and the beginning of July 2011.

Two less intense and shorter (compared to those described above) flash-flooding events were observed on 25-27 May and 30 May 2011 at the southern part of RCBS between the Shakhe and Psou rivers. They caused a moderate increase in the river discharges (up to $25 \mathrm{~m}^{3} \mathrm{~s}^{-1}$ ), except for the Shakhe $\left(50 \mathrm{~m}^{3} \mathrm{~s}^{-1}\right.$ on $25-27$ May) and Psou $\left(85 \mathrm{~m}^{3} \mathrm{~s}^{-1}\right.$ on $30-31$ May) rivers. As a result, the areas of the river plumes were not large enough to collide, so these moderate flooding events did not cause the formation of the freshened alongshore strip.

The influence of a rain-induced flooding event on coastal waters was also studied during a drought period in September 2011. The discharge rates of fluvial water and suspended sediments from the Mzymta, Psou, Shakhe, and Sochi rivers were equal to $6-15 \mathrm{~m}^{3} \mathrm{~s}^{-1}$ and $0.05-0.4 \mathrm{~kg} \mathrm{~s}^{-1}$, whereas the total discharge rates from the small rivers were $10-15 \mathrm{~m}^{3} \mathrm{~s}^{-1}$ and less than $0.1 \mathrm{~kg} \mathrm{~s}^{-1}$, respectively. The spatial scales and salinity anomalies of the river plumes did not exceed $1 \mathrm{~km}$ and 2 PSU. The rain-induced flooding event, which occurred during 10-13 September 2011, caused an increase in discharge of the small rivers by 1 order of magnitude, whereas the discharge of the large rivers rose twofold or less. As a result, the discharge of terrigenous sediments from the small rivers increased by 2 orders of magnitude $\left(1-8 \mathrm{~kg} \mathrm{~s}^{-1}\right)$ and exceeded sediment discharge from the large rivers $(0.5-$ $\left.1 \mathrm{~kg} \mathrm{~s}^{-1}\right)$. However, the total volume of continental discharge 

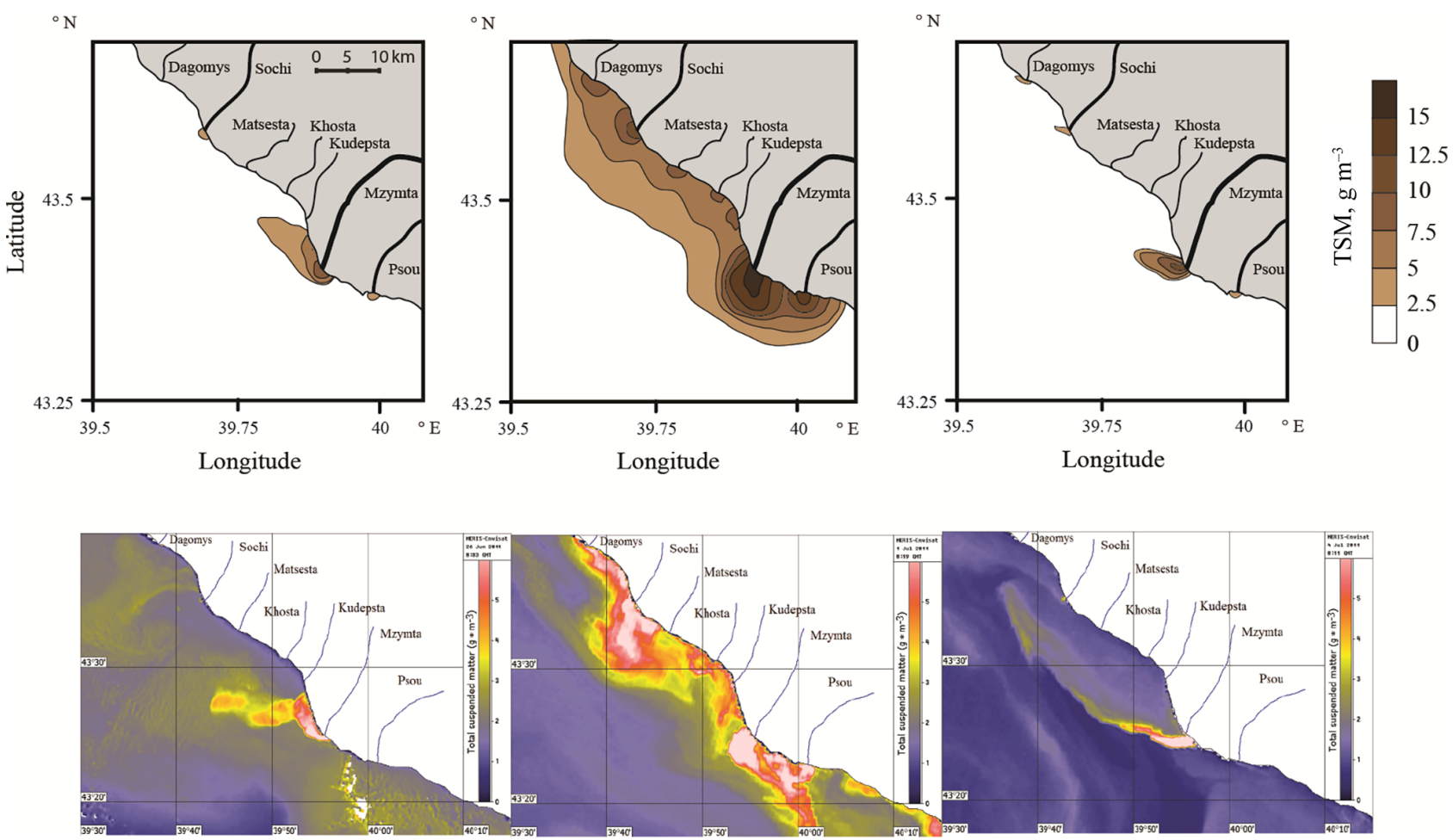

Figure 11. Modeled real mode (top panel) and satellite-derived (bottom panel) surface TSM distributions at the southern part of the study region on 26 June, 1 July, and 4 July 2011.

during 10-13 September 2011 was less than that during 2730 June 2011. A strip of freshened and turbid water was formed between the Pshada and Psou rivers, but it was not continuous and had several gaps $5-10 \mathrm{~km}$ long. The maximal width $(5 \mathrm{~km})$ and depth $(3 \mathrm{~m})$ of the strip were also significantly less than those observed at the end of June 2011. Nevertheless, the geostrophic current $\left(10-20 \mathrm{~cm} \mathrm{~s}^{-1}\right)$ within this strip caused the northeastward transport of fine terrigenous sediments over 4 days until the end of the flash flood on 14 September 2011, when the freshened strip dissipated.

\subsection{Averaged mode numerical experiments}

The averaged mode experiments simulated the delivery and fate of fluvial water and suspended sediments of RCBS during the trial periods in the absence of flooding events. Averaging the discharge hydrographs over a period of 10 days significantly influenced the small rivers by reducing the peak discharge values. As a result, the variability of the total discharge of the small rivers during the first trial period changed from $21-224 \mathrm{~m}^{3} \mathrm{~s}^{-1}$ in the real mode to $40-108 \mathrm{~m}^{3} \mathrm{~s}^{-1}$ in the averaged mode. Averaging the discharge rates of the large rivers of RCBS modified them less considerably, e.g., the variability of the Mzymta discharge changed from 47-139 to $54-91 \mathrm{~m}^{3} \mathrm{~s}^{-1}$.

Under the averaged discharge conditions, the Mzymta and Psou rivers were the only significant sources of fluvial wa- ter and terrigenous sediments during the whole first trial period. Spatial scales of the Mzymta and Psou plumes exceeded $10 \mathrm{~km}$, whereas the other rivers did not form plumes greater than $1-2 \mathrm{~km}^{2}$ even during the period of their maximal discharge on 1 July 2011 (Fig. 12). The total sediment discharge rate of the Mzymta and Psou rivers was $8-28 \mathrm{~kg} \mathrm{~s}^{-1}$, whereas the total discharge rate of all the other rivers did not exceed $3.5 \mathrm{~kg} \mathrm{~s}^{-1}$. Thus, the point-source discharge pattern was observed during the whole first trial period. Coarse fractions of suspended sediments were deposited mainly near the Mzymta and Psou estuaries, whereas fine fractions were transported offshore to the deep ocean by ambient coastal circulation.

During the second trial period, spatial scales of all the river plumes of RCBS under the averaged discharge conditions were less than $1 \mathrm{~km}$. As a result, the point-source discharge pattern was observed during the whole trial period. Owing to the absence of flooding events characterized by intense sediment runoff, the daily sediment discharge from RCBS under the averaged discharge conditions was much smaller than that under the real discharge conditions and did not exceed $3 \mathrm{~kg} \mathrm{~s}^{-1}$. Thus, the rate of sediment load to the seabed was negligible under these conditions throughout the whole study area. 

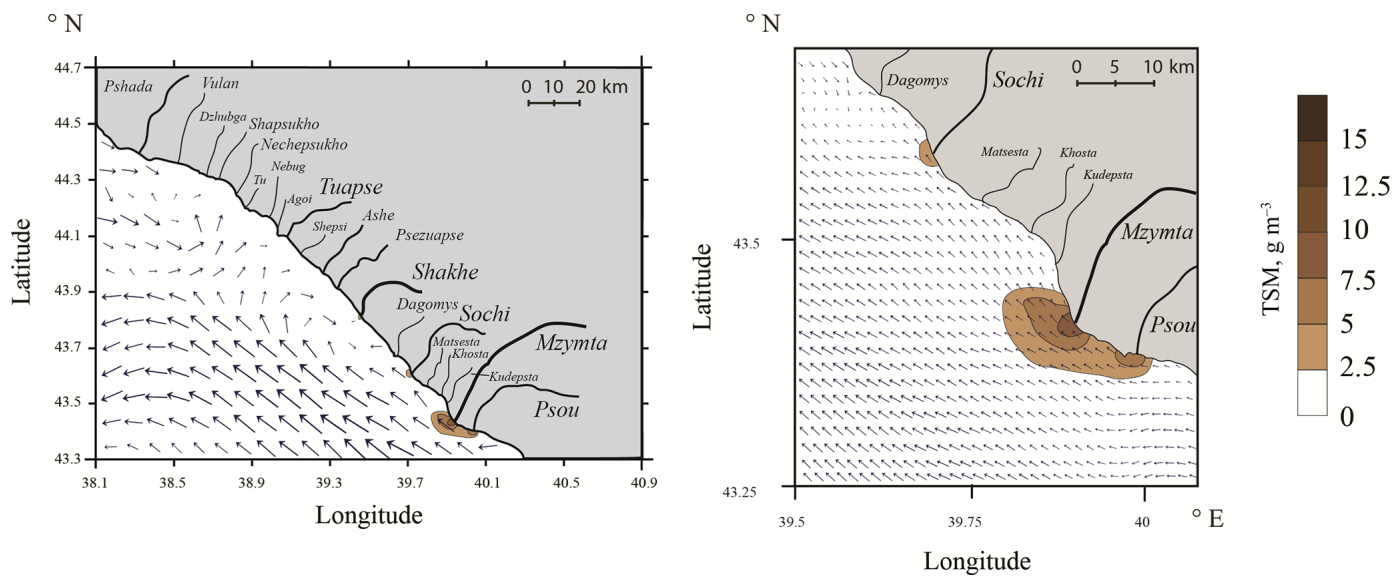

Figure 12. Modeled surface TSM distribution at RCBS (left) and its southern part (right) under the averaged mode on 1 July 2011.
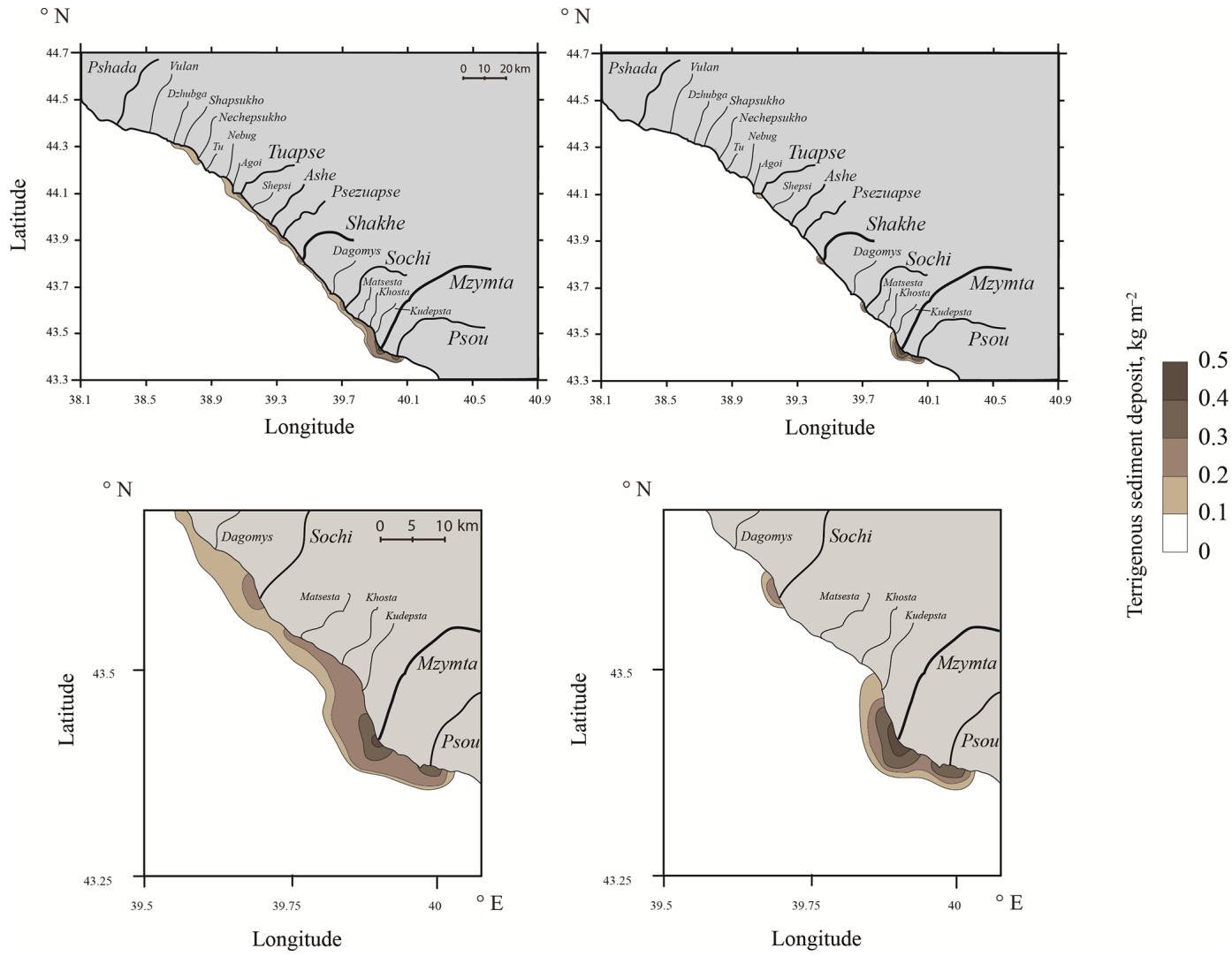

Figure 13. Simulated distribution of terrigenous sediments discharged from the rivers of the study area during 25 May to 4 July 2011 and deposited on the seabed at RCBS (top panel) and its southern part (bottom panel) under the real (left) and averaged (right) modes.

\subsection{Sediment transport and deposition}

Besides salinity and TSM distributions at the study area, the nested model simulated the transport and settling of riverborne terrigenous sediments discharged from the rivers of RCBS during the first trial period under real and averaged discharge conditions. The obtained distributions of terrige- nous sediments deposited on the seabed at the study area are presented in Fig. 13.

The total discharge volumes from the individual rivers during the first trial period were the same for both simulation modes; however, the daily discharge rates were significantly different, especially during flash-flooding periods. Owing to nonlinearity of the dependence of sediment discharge rate on 
water discharge rate, the total sediment flux from the modeled rivers during 41 days of the first trial period under the real mode $\left(8.5 \times 10^{7} \mathrm{~kg}\right)$ was greater by a quarter than under the averaged mode $\left(6.7 \times 10^{7} \mathrm{~kg}\right)$.

The resulting deposit patterns obtained for the two modes were also significantly different. Under the averaged discharge conditions, most of the river-borne sediments were discharged from the Mzymta, Psou, Sochi, Shakhe, and Tuapse rivers and were deposited near their estuaries. The region of the most active sediment load $\left(0.2-0.5 \mathrm{~kg} \mathrm{~m}^{-2}\right)$ provided by the Mzymta and Psou rivers was located at the southern part of the study region, and its alongshore extent and area were approximately 20 and $60 \mathrm{~km}^{2}$. The area of the region adjacent to the Mzymta estuary, where sediment load exceeded $0.4 \mathrm{~kg} \mathrm{~m}^{-2}$, was approximately $5 \mathrm{~km}^{2}$.

As in the averaged mode run, the Mzymta and Psou rivers were major sources of suspended sediments at the study region under the real discharge conditions. However, the flashflooding events, reproduced in the real mode, resulted in significant sediment runoff from the other rivers of RCBS. Moreover, the formation of strong alongshore geostrophic currents of turbid and freshened water on 21 to 24 June and 29 June to 2 July 2011 resulted in an intense transport of sediments along the shore in a northwestern direction. In particular, large volumes of sediments discharged from the large southern rivers (Psou, Mzymta, Sochi, and Shakhe) were transported several tens of kilometers from their sources and settled on the seabed at the large segments of the shelf area. As a result, sediment load exceeded $0.1 \mathrm{~kg} \mathrm{~m}^{-2}$ along almost the whole shore between the Psou and Dzhubga rivers. The total alongshore length of the coast influenced by active sedimentation was approximately $150 \mathrm{~km}$, which is significantly greater than the corresponding length $(35 \mathrm{~km})$ observed under the averaged discharge conditions.

\section{$7 \quad$ Summary and conclusions}

This study focused on the influence of the river plumes of RCBS on the delivery and fate of fluvial water and terrigenous sediments under average climatic and flooding discharge conditions. We used a nested combination of the INMOM and the STRiPE. The Eulerian model INMOM reproduced general ocean circulation at the northeastern part of the Black Sea and provided boundary conditions for the Lagrangian model STRiPE, which was used for simulating the dynamics of river plumes. The model was validated against in situ measurements and satellite imagery. To study the influence of flash floods on the delivery and fate of fluvial water and terrigenous sediments during freshet and drought seasons, we considered two trial periods: 25 May to 4 July 2011 and 6-19 September 2011. Based on in situ data, satellite imagery, and numerical modeling, we reconstructed the daily values of fluvial water and terrigenous sediments discharged during the trial periods from the 20 largest rivers of the study region. Then, for both trial periods, we simulated the spread of buoyant plumes in two modes: first, using reconstructed discharge data (real mode) and, second, excluding flash-flooding periods by averaging the discharge data over a period of 10 days (averaged mode).

Numerical experiments showed that short-term raininduced flooding events significantly influence sediment transport and deposition patterns at RCBS. Under average climatic discharge conditions, the total runoff of fluvial water and terrigenous sediments is dominated by several of the largest rivers of the study area. Water and sediment yield from the small rivers is low; therefore, their plumes have small spatial scales and high dissipation rates, and their impact on coastal water quality is negligible. As a result, continental discharge significantly influences water quality and induces intense sediment load only near the estuaries of large rivers.

Active precipitation events can cause a rapid and substantial increase in water and sediment discharge from the small rivers of RCBS and can induce the formation of flashflooding conditions at long segments of the seashore during both freshet and drought seasons. Under these conditions, the areas of the river plumes increase significantly, and individual plumes can collide and coalesce with neighboring ones. As a result, the related change of the discharge pattern from point-source to line-source can cause the formation of one or several alongshore strips of freshened and turbid water up to $200 \mathrm{~km}$ and markedly transform the transport pathways of river-borne suspended and dissolved matter at the study region. These strips influence the dynamics of river plumes by decreasing the mixing intensity between the plumes and ambient water, thus increasing the spatial scales of the river plumes. Also, alongshore geostrophic currents of turbid and freshened water, which are formed within these strips, induce the intense transport of sediments in a northwestern direction and their settling along the shore. This process significantly influences coastal water quality and causes active sediment load at large segments of the narrow shelf of RCBS compared to average climatic discharge conditions.

As shown above, flash-flooding events influence the discharge from small rivers to a larger extent compared to large rivers. Therefore, the annual distribution of precipitation, in particular frequency, intensity, and time spacing of extreme precipitation events, significantly affects the landocean fluxes of freshwater, dissolved matter, and suspended matter.

In particular, a steady increase in air temperature of $1.2-$ $1.4{ }^{\circ} \mathrm{C}$ and in annual precipitation volume of $32-164 \mathrm{~mm}$ was registered at meteorological stations of RCBS in 19712010, which caused climate-driven changes in the discharge regimes of rivers of the study region. The annual frequency and duration of heavy rain events and, therefore, the annual number of extreme river floods have also shown increasing tendency in the last 50 years (Alexeevsky et al., 2016). Moreover, maximal annual discharge volumes increased by $1.5-$ 
4.5 times for all the rivers of RCBS during this period. As a result, owing to these climate-driven changes, the extreme flooding events addressed in this study tend to increase their role in local land-ocean fluxes and in the coastal transport of freshwater, terrigenous sediments, nutrients, and pollutants.

RCBS is a densely populated area (approximately 1.1 million people) and the most important recreational area of Russia, which is visited by more than 10 million people annually. Of the residential and visitor population, $95 \%$ is located at the narrow coastal area less than $10 \mathrm{~km}$ from the seashore; therefore, correct evaluation of the influence of small rivers on coastal water quality is extremely important for this region.

The influence of small rivers can be also significant for many world regions that have similar configurations of rivers flowing into the sea, i.e., close spacing of river mouths, steep and small river basins, and frequent flash-flooding events. In particular, this configuration is typical of mountainous coastal areas with humid climates, e.g., Chile (Saldias et al., 2012, 2016), the southwestern coast of USA (Mertes and Warrick, 2001; Nezlin et al., 2008), the southwestern coast of New Zealand, and the southeastern coast of Papua New Guinea. Thus, the results obtained in this study, related to differences in transport patterns of terrigenous sediments under point-source and line-source discharge conditions, could be applied for many coastal areas such as those described above.

Finally, global catchment-based models, which are widely used for the estimation of freshwater, suspended sediment, and nutrient loads, e.g., NEWS 2 (Mayorga et al., 2010) and IMAGE-GNM (Beusen et al., 2015), have insufficient spatial resolution to reconstruct discharges from small rivers. However, neglecting their role can result in underestimation of volumes of related land-ocean fluxes for many coastal areas, at least on the synoptic timescale. Therefore, this study can be useful for improvement of quantitative assessments of global catchment-based models.

Data availability. The satellite data were downloaded from the European Space Agency repository of the Envisat satellite data http:// merisfrs-merci-ds.eo.esa.int/merci (available after registration) and the Copernicus Marine Environment Monitoring Service repository $\mathrm{ftp} / / / \mathrm{cmems}$.isac.cnr.it (available after registration). The river discharge data were downloaded from the Federal Service for Hydrometeorology and Environmental Monitoring of Russia repository http://gis.vodinfo.ru/ (available after registration). The in situ data and files necessary to reproduce the simulations are available from the authors upon request.

Competing interests. The authors declare that they have no conflict of interest.
Acknowledgements. The authors are grateful to many colleagues from Shirshov Oceanology Institute for valuable support during the fieldwork and wish to thank Peter Zavialov, Nikolay Diansky, Dmitry Soloviev, Vadim Pelevin, Boris Konovalov, Alevtina Alyukaeva, and Vladimir Belokopytov, whose data were used in this study. The authors wish to thank the European Space Agency and the Copernicus Marine Environment Monitoring Service for the provided satellite data and the Federal Service for Hydrometeorology and Environmental Monitoring of Russia for the provided river-discharge data. This research was funded by the Russian Ministry of Science and Education (research project 14.W03.31.0006).

Edited by: Piers Chapman

Reviewed by: two anonymous referees

\section{References}

Alexeevsky, N., Magritsky, D. V., Koltermann, K. P., Krylenko, I., and Toropov, P.: Causes and systematics of inundations of the Krasnodar territory on the Russian Black Sea coast, Nat. Hazards Earth Syst. Sci., 16, 1289-1308, https://doi.org/10.5194/nhess16-1289-2016, 2016.

Balabanov, I. P., Nikiforov, S. P., and Pashkovskiy, I. S.: Imeretinskaya lowland. Natural and geological conditions, development problems, Nedra, Moscow, Russia, 2011 (in Russian).

Bao, H., Huang, T. Y. L. J. C., Feng, X., Dai, M., and Kao, S. J.: Importance of Oceanian small mountainous rivers (SMRs) in global land-to-ocean output of lignin and modern biospheric carbon, Sci. Rep., 5, 16217, https://doi.org/10.1038/srep16217, 2015.

Beusen, A. H. W., Van Beek, L. P. H., Bouwman, A. F., Mogollón, J. M., and Middelburg, J. J.: Coupling global models for hydrology and nutrient loading to simulate nitrogen and phosphorus retention in surface water - description of IMAGE-GNM and analysis of performance, Geosci. Model Dev., 8, 4045-4067, https://doi.org/10.5194/gmd-8-4045-2015, 2015.

Brodie, J., Schroeder, T., Rohde, K., Faithful, J., Masters, B., Dekker, A., Brando, V., and Maughan, M.: Dispersal of suspended sediments and nutrients in the Great Barrier Reef lagoon during river-discharge events: conclusions from satellite remote sensing and concurrent flood-plume sampling, Mar. Freshwater Res., 61, 651-664, https://doi.org/10.1071/MF08030, 2010.

Danabaoglu, G., Yeager, S. G., Kim, W. M., Behrens, E., Bentsen, M., Bi, D., Biastoch, A., Bleck, R., Böning, C., Bozec, A., Canuto, V. M., Cassou, C., Chassignet, E., Coward, A. C., Danilov, S., Diansky, N., Drange, H., Farneti, R., Fernandez, E., Fogli, P. G., Forget, G., Fujii, Y., Griffies, S. M., Gusev, A., Heimbach, P., Howard, A., Ilicak, M., Jung, T, Karspeck, A. R., Kelley, M., Large, W. G., Leboissetier, A., Lu, J., Madec, G., Marsland, S. J., Masina, S., Navarra, A., Nurser, A. G. J., Pirani, A., Romanou, A., Mélia, D. S., Samuels, B. L., Scheinert, M., Sidorenko, D., Sun, S., Treguier, A.-M., Tsujino, H., Uotila, P., Valcke, S., Voldoire, A., Wang, Q., and Yashayaev, I. :North Atlantic simulations in Coordinated Ocean-ice Reference Experiments phase II (CORE-II). Part II: Inter-annual to decadal variability, Ocean Modell., 97, 65-90, https://doi.org/10.1016/j.ocemod.2015.11.007, 2016. 
Diansky, N. A., Fomin, V. V., Zhokhova, N. V., and Korshenko, A. N.: Simulations of currents and pollution transport in the coastal waters of Big Sochi, Izv. Atmos. Oceanic Phys., 49, 611-621, https://doi.org/10.1134/s0001433813060042, 2013.

Doerffer, R. and Schiller, H.: MERIS regional, coastal and lake case 2 water project - atmospheric correction ATBD, Version 1.0, 18 May 2008, GKSS Research Center, Geesthacht, Germany, 2008.

Downes, S. M., Farneti, R., Uotila, P., Griffies, S. M., Marsland, S. J., Bailey, D., Behrens, E., Bentsen, M., Bi, D., Biastoch, A., Böning, C., Bozec, A., Canuto, V. M., Chassignet, E., Danabasoglu, G., Danilov, S., Diansky, N., Drange, H., Fogli, P. G., Gusev, A., Howard, A., Ilicak, M., Jung, T., Kelley, M., Large, W. G., Leboissetier, A., Long, M., Lu, J., Masina, S., Mishra, A., Navarra, A, Nurser, A. G. J., Patara, L., Samuels, B. L., Sidorenko, D., Spence, P., Tsujino, H., Wang, Q., and Yeager, S. G.: An assessment of Southern Ocean water masses and sea ice during 1988-2007 in a suite of interannual CORE-II simulations, Ocean Modell., 94, 67-94, https://doi.org/10.1016/j.ocemod.2015.07.022, 2015.

Emmett, R. L., Krutzikowsky, G. K., and Bentley, P.: Abundance and distribution of pelagic piscivorous fishes in the Columbia River plume during spring/early summer 1998-2003: relationship to oceanographic conditions, forage fishes, and juvenile salmonids, Prog. Oceanogr., 68, 1-26, https://doi.org/10.1016/j.pocean.2005.08.001, 2006.

Enriquez, C. E., Shapiro, G. I., Souza, A. J., and Zatsepin, A. G.: Hydrodynamic modelling of mesoscale eddies in the Black Sea, Ocean Dyn., 55, 476-489, https://doi.org/10.1007/s10236-0050031-4, 2005.

Farneti, R., Downes, S. M., Griffies, S. M., Marsland, S. J., Behrens, E., Bentsen, M., Bi, D., Biastoch, A., Böning, C., Bozec, A., Canuto, V. M., Chassignet, E., Danabasoglu, G., Danilov, S., Diansky, N., Drange, H., Fogli, P. G., Gusev, A., Hallberg, R. W., Howard, A., Ilicak, M., Jung, T., Kelley, M., Large, W. G., Leboissetier, A., Long, M., Lu, J., Masina, S., Mishra, A., Navarra, A, Nurser, A. G. J., Patara, L., Samuels, B. L., Sidorenko, D., Tsujino, H., Uotila, P., Wang, Q., and Yeager, S. G.: An assessment of Antarctic Circumpolar Current and Southern Ocean meridional overturning circulation during 19582007 in a suite of interannual CORE-II simulations, Ocean Modell., 93, 84-120, https://doi.org/10.1016/j.ocemod.2015.07.009, 2015.

Fong, D. A. and Geyer, W. R.: The alongshore transport of freshwater in a surface-trapped river plume, J. Phys. Oceanogr., 32, 957-972. https://doi.org/10.1175/15200485(2002)032<0957:TATOFI>2.0.CO;2, 2002.

Garvine, R. W.: Estuary plumes and fronts in shelf waters: A layer model, J. Phys. Oceanogr., 17, 1877-1896, https://doi.org/10.1175/15200485(1987)017<1877:epafis>2.0.co;2, 1987.

Ginzburg, A. I., Kostianoy, A. G., Krivosheya, V. G., Nezlin, N. P., Soloviev, D. M., Stanichny, S. V., and Yakubenko, V. G.: Mesoscale eddies and related processes in the northeastern Black Sea, J. Mar. Syst., 32, 71-90, https://doi.org/10.1016/s04229894(00)80016-1, 2002.

Gregg, M. C. and Ozsoy, E.: Mixing on the Black Sea shelf north of the Bosphorus, Geophys. Res. Lett., 26, 1869-1872, https://doi.org/10.1029/1999GL900431, 1999.
Hilton, R. G., Galy, A., Hovius, N., Horng, M.-J., and Chen, H.: Efficient transport of fossil organic carbon to the ocean by steep mountain rivers: An orogenic carbon sequestration mechanism, Geology, 39, 71-74, https://doi.org/10.1130/g31352.1, 2011.

Horner-Devine, A. R., Fong, D. A., Monismith, S. G., and Maxworthy, T.: Laboratory experiments simulating a coastal river discharge, J. Fluid Mech., 555, 203-232, https://doi.org/10.1017/s0022112006008937, 2006.

Hrachowitz, M., Savenije, H. H. G., Blöschl, G., McDonnelld, J. J., Sivapalan, M., Pomeroyg, J. W., Arheimer, B., Blume, T., Clark, M. P., Ehret, U., Fenicia, F., Freer, J. E., Gelfan, A., Gupta, D. A., Hughes, R. W., Hut, A., Montanari, S., Pande, D., Tetzlaff, P. A., Troch, S., Uhlenbrook, H. V., Wagener, T., Winsemius, H. C., Woods, R. A., Zehe, E., and Cudennec C.: A decade of Predictions in Ungauged Basins (PUB) - a review, Hydrol. Sci. J., 58, 1198-1255, https://doi.org/10.1080/02626667.2013.803183, 2013.

Ivanov, V. A. and Belokopytov, V. N.: Oceanography of the Black Sea, ECOSY-Gidrofizika, Sevastopol, 17-19, 2013.

Jaoshvili, S.: River sediment and beach formation on the Black Sea coast of Georgia, Sabchota Sakartvelo, Tbilisi, USSR, 1986 (in Russian).

Jaoshvili, S.: The rivers of the Black Sea, European Environmental Agency, eds. I. Chomeriki, G. Gigineishvili, and A. Kordzadze, Technical Report No. 71, 2002.

Johnson, M., Proshutinsky, A., Aksenov, Y., Nguyen, A. T., Lindsay, R., Haas, C., Zhang, J., Diansky, N., Kwok, R., Maslowski, W., Häkkinen, S., Ashik, I., and Cuevas, B.: Evaluation of Arctic sea ice thickness simulated by Arctic Ocean Model Intercomparison Project models, J. Geophys. Res., 117, C00D13, https://doi.org/10.1029/2011JC007257, 2012.

Kniskern, T. A., Warrick, J. A., Farnsworth, K. L., Wheatcroft, R. A., and Goni, M. A.: Coherence of river and ocean conditions along the US West Coast during storms, Cont. Shelf Res., 31, 789-805, https://doi.org/10.1016/j.csr.2011.01.012, 2011.

Korotaev, G., Oguz, T., Nikiforov, A., and Koblinsky, C.: Seasonal, interannual, and mesoscale variability of the Black Sea upper layer circulation derived from altimeter data, J. Geophys. Res., 108, 3122, https://doi.org/10.1029/2002jc001508, 2003.

Korotenko, K. A., Osadchiev, A. A., Zavialov, P. O., Kao, R.-C., and Ding, C.-F.: Effects of bottom topography on dynamics of river discharges in tidal regions: case study of twin plumes in Taiwan Strait, Ocean Sci., 10, 863-879, https://doi.org/10.5194/os10-863-2014, 2014.

Korotkina, O. A., Zavialov P. O., and Osadchiev A. A.: Submesoscale variability of the current and wind fields in the coastal region of Sochi, Oceanology, 51, 745-754, https://doi.org/10.1134/s0001437011050109, 2011.

Korotkina, O. A., Zavialov P. O., and Osadchiev A. A.: Synoptic variability of currents in the coastal waters of Sochi, Oceanology, 54, 545-556, https://doi.org/10.1134/s0001437014040079, 2014.

Kubryakov, A. A. and Stanichny, S. V.: Mesoscale eddies in the Black Sea from satellite altimetry data, Oceanology, 55, 56-67, https://doi.org/10.1134/s0001437015010105, 2015a.

Kubryakov, A. A. and Stanichny, S. V.: Seasonal and interannual variability of the Black Sea eddies and its dependence on characteristics of the large-scale circulation, Deep Sea Res. Part I, 97, 80-91, https://doi.org/10.1016/j.dsr.2014.12.002, 2015b. 
Mayorga, E., Seitzinger, S. P., Harrison, J. A., Dumont, E., Beusen, A. H., Bouwman, A. F., Fekete, B. M., Kroeze, C., and Van Drecht, G.: Global nutrient export from WaterSheds 2 (NEWS 2): model development and implementation, Environ. Modell. Software, 25, 837-853, https://doi.org/10.1016/j.envsoft.2010.01.007, 2010.

Mertes, L. A. K. and Warrick, J. A.: Measuring flood output from 110 coastal watersheds in California with field measurements and SeaWiFS, Geology, 29, 659-662, https://doi.org/10.1130/00917613(2001)029<0659:mfofcw>2.0.co;2, 2001

Meybeck, M., Laroche, L., Dürr, H. H., and Syvitski, J. P. M.: Global variability of daily total suspended solids and their fluxes in rivers, Global Planet. Change, 39, 65-93, https://doi.org/10.1016/s0921-8181(03)00018-3, 2003.

Milliman, J. D. and Syvitski, J. P. M.: Geomorphic-tectonic control of sediment discharge to the ocean: the importance of small mountainous rivers, J. Geol., 100, 525-544, https://doi.org/10.1086/629606, 1992.

Milliman, J. D., Lin, S. W., Kao, S. J., Liu, J. P., Liu, C. S., Chiu, J. K., and Lin, Y. C.: Short-term changes in seafloor character due to flood-derived hyperpycnal discharge: typhoon Mindulle, Taiwan, July 2004, Geology, 35, 779-782, https://doi.org/10.1130/g23760a.1, 2007.

Nardelli, B. B., Colella, S., Santoleri, R., Guarracino, M., and Kholod, A.: A re-analysis of Black Sea Surface Temperature, J. Mar. Sys.., 79, 50-64, https://doi.org/10.1016/j.jmarsys.2009.07.001, 2009.

Nardelli, B. B., Tronconi, C., Pisano, A., and Santoleri, R.: High and Ultra-High resolution processing of satellite Sea Surface Temperature data over Southern European Seas in the framework of MyOcean project, Rem. Sens. Env., 129, 1-16, https://doi.org/10.1016/j.rse.2012.10.012, 2013.

Nezlin, N. P., DiGiacomo, P. M., Diehl, D. W., Jones, B. H., Johnson, S. C., Mengel, M. J., Reifel, K. M., Warrick, J. A., and Wang, M.: Stormwater plume detection by MODIS imagery in the southern California coastal ocean, Estuarine Coast. Shelf Sci., 80, 141-152, https://doi.org/10.1016/j.ecss.2008.07.012, 2008.

O'Donnell J.: The formation and fate of a river plume: A numerical model, J. Phys. Oceanogr., 20, 551-569, https://doi.org/10.1175/1520-0485(1990)020<0551:tfafoa> 2.0.co;2, 1990.

Oguz, T., La Violette, P. E., and Unluata, U.: The upper layer circulation of the Black Sea: its variability as inferred from hydrographic and satellite observations, J. Geophys. Res.-Oceans, 97, 12569-12584, https://doi.org/10.1029/92jc00812, 1992.

Oguz, T., Latun, V. S., Latif, M. A., Vladimirov, V. V., Sur, H. I., Markov, A. A., Ozsoy, E., Kotovshchikov B. B., Eremeev, V. V., and Unluata, U.: Circulation in the surface and intermediate layers of the Black Sea, Deep Sea Res. Part I, 40, 1597-1612, https://doi.org/10.1016/0967-0637(93)90018-X, 1993.

Oguz, T., Malanotte-Rizzoli, P., and Aubrey, D.: Wind and thermohaline circulation of the Black Sea driven by yearly mean climatological forcing, J. Geophys. Res.-Oceans, 100, 6845-6863, https://doi.org/10.1029/95JC00022, 1995.

Osadchiev A. A.: A method for quantifying freshwater discharge rates from satellite observations and Lagrangian numerical modeling of river plumes, Environ. Res. Lett., 10, 085009 , https://doi.org/10.1088/1748-9326/10/8/085009, 2015.

Osadchiev, A. A., Korotenko, K. A., Zavialov, P. O., Chiang, W.-S., and Liu, C.-C.: Transport and bottom accumulation of fine river sediments under typhoon conditions and associated submarine landslides: case study of the Peinan River, Taiwan, Nat. Hazards Earth Syst. Sci., 16, 41-54, https://doi.org/10.5194/nhess-16-412016, 2016.

Osadchiev, A. A. and Zavialov, P. O.: Lagrangian model for surface-advected river plume, Cont. Shelf Res., 58, 96-106, https://doi.org/10.1016/j.csr.2013.03.010, 2013.

Pacanowsky, R. C. and Philander, G.: Parameterization of vertical mixing in numerical models of the tropical ocean, $\mathrm{J}$. Phys. Oceanogr., 11, 1442-1451, https://doi.org/10.1175/15200485(1981)011<1443:povmin>2.0.co;2, 1981.

Palmer, S. C., Pelevin, V. V., Goncharenko, I., Kovacs, A. W., Zlinszky, A., Presing, M., Horvath, H., Nicolas-Perea, V., Balzter, H., and Toth, V. R.: Ultraviolet Fluorescence LiDAR (UFL) as a measurement tool for water quality parameters in turbid lake conditions, Remote Sensing, 5, 4405-4422, https://doi.org/10.3390/rs5094405, 2013.

Rabalais, N. N.: Eutrophication of estuarine and coastal ecosystems, Environmental Microbiology, 2nd edition, edited by: Mitchell, R. and Gu, J.-D., Hoboken, NJ: Wiley, 115-134, 2010.

Saldias, G. S., Sobarzo, M., Largier, J., Moffat, C., and Letelier, R.: Seasonal variability of turbid river plumes off central Chile based on high-resolution MODIS imagery, Remote Sens. Env., 123, 220-233, https://doi.org/10.1016/j.rse.2012.03.010, 2012.

Saldias, G. S., Largier, J. L., Mendes, R., Pérez-Santos, I., Vargas, C. A., and Sobarzo, M.: Satellite-measured interannual variability of turbid river plumes off central-southern Chile: Spatial patterns and the influence of climate variability, Prog. Oceanogr., 146, 212-222, https://doi.org/10.1016/j.pocean.2016.07.007, 2016.

Stanev, E. V., Roussenov, V. M., Rachev, N. H., and Staneva, J. V.: Sea response to atmospheric variability. Model study for the Black Sea, J. Mar. Syst., 6, 241-267, https://doi.org/10.1016/0924-7963(94)00026-8, 1995.

Staneva, J. V., Dietrich, D. E., Stanev, E. V., and Bowman, M. J.: Rim current and coastal eddy mechanisms in an eddy-resolving Black Sea general circulation model, J. Mar. Syst., 31, 137-157, https://doi.org/10.1016/s0924-7963(01)00050-1, 2001.

Titov, V. B.: Characteristics of the Main Black Sea Current and nearshore anticyclonic eddies in the Russian sector of the Black Sea, Oceanology, 42, 637-645, 2002.

Volodin, E. M., Diansky, N. A., and Gusev, A. V.: Simulating present-day climate with the INMCM4.0 coupled model of the atmospheric and oceanic general circulations, Izv., Atmos. Ocean. Phys., 46, 414-431, https://doi.org/10.1134/s000143381004002x, 2010.

Vorosmarty, C., Askew, A., Grabs, W., Barry, R. G., Birkett, C., Doll, P., Goodison, B., Hall, A., Jenne, R., Kitaev, L., Landwehr, J., Keeler, M., Leavesley, G., Schaake, J., Strzepek, K., Sundarvel, S. S., Takeuchi, K., and Webster, F.: Global water data: a newly endangered species, Eos, Trans. Amer. Geophys. Union., 82, 54-58, https://doi.org/10.1029/01 eo00031, 2001.

Warrick, J. A. and Farnsworth, K. L.: Coastal river plumes: collisions and coalescence, Prog. Oceanogr., 151, 245-260, https://doi.org/10.1016/j.pocean.2016.11.008, 2017. 
Wheatcroft, R. A., Goni, M. A., Hatten, J. A., Pasternack, G. B., and Warrick, J. A.: The role of effective discharge in the ocean delivery of particulate organic carbon by small, mountainous river systems, Limnol. Oceanogr., 55, 161-171, https://doi.org/10.4319/lo.2010.55.1.0161, 2010.

Zalesny, V. B., Diansky, N. A., Fomin, V. V., Moshonkin, S. N., and Demyshev, S. G.: Numerical model of the circulation of the Black Sea and the Sea of Azov, Rus. J. Numer. Anal. Math. Modelling, 27, 95-112, https://doi.org/10.1515/rnam2012-0006, 2012.

Zalesny, V. B., Gusev, A. V., and Moshonkin, S. N.: Numerical model of the hydrodynamics of the Black Sea and the Sea of Azov with variational initialization of temperature and salinity, Izv., Atmos. Ocean. Phys., 49, 642-658, https://doi.org/10.1134/S0001433813060133, 2013.

Zalesny, V. B., Gusev, A. V., Lukyanova, A. N., and Fomin, V. V.: Numerical modelling of sea currents and tidal waves, Russ. J. Numer. Anal. Math. Modelling, 31, 115-125, https://doi.org/10.1515/rnam-2016-0012, 2016a.

Zalesny, V. B., Gusev, A. V., and Agoshkov, V. I.: Modeling Black Sea circulation with high resolution in the coastal zone, Izv., Atmos. Ocean. Phys., 52, 277-293, https://doi.org/10.1134/S0001433816030142, 2016b.
Zatsepin, A. G., Ginzburg, A. I., Kostianoy, A. G., Kremenetskiy, V. V., Krivosheya, V. G., Poulain, P.- M., and Stanichny, S. V.: Observation of Black Sea mesoscale eddies and associated horizontal mixing, J. Geophys. Res., 108, 1-27, https://doi.org/10.1029/2002jc001390, 2003.

Zavialov, P. O., Makkaveev, P. N., Konovalov, B. V., Osadchiev, A. A., Khlebopashev, P. V., Pelevin, V. V., Grabovskiy, A. B., Izhitskiy, A. S., Goncharenko, I. V., Soloviev, D. M., and Polukhin, A. A.: Hydrophysical and hydrochemical characteristics of the sea areas adjacent to the estuaries of small rivers if the Russian coast of the Black Sea, Oceanology, 54, 265-280, https://doi.org/10.1134/s0001437014030151, 2014.

Zhou, M.-J., Shen, Z.-L., and Yu, R.-C.: Responses of a coastal phytoplankton community to increased nutrient input from the Changjiang (Yangtze) River, Cont. Shelf Res., 28, 1483-1489, https://doi.org/10.1016/j.csr.2007.02.009, 2008. 